\title{
Unstable Rifts, a Leaky Transform Zone and a Microplate: Analogues from South Iceland
}

\author{
Maryam Khodayar¹, Sveinbjörn Björnsson², Skúli Víkingsson³, Guðrún Sigríður Jónsdóttir³ \\ ${ }^{1}$ Consultant and Researcher in Geosciences, Reykjavík, Iceland \\ ${ }^{2}$ National Energy Authority of Iceland, Reykjavík, Iceland \\ ${ }^{3}$ Iceland GeoSurvey (ISOR), Reykjavík, Iceland \\ Email: Profnet10@mail.com, svb@orkugardur.is, sv@isor.is, gsj@isor.is
}

How to cite this paper: Khodayar, M., Björnsson, S., Víkingsson, S. and Jónsdóttir, G.S. (2020) Unstable Rifts, a Leaky Transform Zone and a Microplate: Analogues from South Iceland. Open Journal of Geology, 10, 317-367.

https://doi.org/10.4236/ojg.2020.104017

Received: December 30, 2019

Accepted: April 14, 2020

Published: April 17, 2020

Copyright $\odot 2020$ by author(s) and Scientific Research Publishing Inc. This work is licensed under the Creative Commons Attribution-NonCommercial International License (CC BY-NC 4.0).

http://creativecommons.org/licenses/by-nc/4.0/

\begin{abstract}
A structural analysis was undertaken in the South Iceland Seismic Zone (SISZ) transform zone, and in the Hreppar Microplate (HMP) located between the propagating Eastern Rift Zone (ERZ) and the receding Western Rift Zone (WRZ). The age of the oceanic crust in these areas is $3.4 \mathrm{Ma}$ to present. About 20,000 fracture segments on aerial images reflect the dominance of NNE extensional structures in the WRZ. Around 9,000 basement faults, intrusions, secondary fractures, surface ruptures of earthquakes, and leakages were mapped in the outcrops of the HMP and the SISZ. About 23\% of these fractures strike NNE, while $77 \%$ are dominantly northerly dextral and ENE sinistral, and secondarily E-W, WNW and NW sinistral strike- and oblique-slip structures, forming a Riedel shear pattern typical of a transform zone. Dyke injections into Riedel shears indicate a leaky transform zone. Fractures reactivated, accumulated slip, and re-opened for fluid flow. The ENE faults dip mostly to the southeast and could be the present boundary of the SISZ to the north. A $10-30 \mathrm{~km}$ wide ENE structural zone hosts a valley to the east, which could be deeper in the west. This ENE zone contains all the earthquakes, dominant ENE rivers, frequent ENE secondary fractures, and is likely the active part of the SISZ. The HMP does not show rotation since 3.4 Ma despite being between two rift segments. Future propagation/recession of the rift segments along their $\mathrm{N} 55^{\circ} \mathrm{E}$ sections would cause a migration and a clockwise rotation of the SISZ from ENE to E-W. The boundary faults of the SISZ would then be E-W, with unchanged internal Riedel shears, compensating its sinistral motion. Insights into complexities of diverging plate boundaries are critical for resource management in such tectonic contexts.
\end{abstract}

\section{Keywords}

Unstable Diverging Plate Boundaries, South Iceland Seismic Zone, Leaky Transform Zone, Rotation of Microplate, Tectonics of Iceland 


\section{Introduction}

Iceland is a surface expression of a Mid Ocean Ridge, above a hotspot, and a Tertiary member of the North Atlantic Igneous Province associated with the opening of the North Atlantic since 62 - $58 \mathrm{Ma}$ [1] [2]. Presently, the American and Eurasian plates separate in the direction of $\sim \mathrm{N} 105^{\circ} \mathrm{E}$ [3] along active plate boundaries. However, divergence since Tertiary has also led to a series of extinct rift and transform segments and associated structures in Iceland (Figure 1(a)). The study area covers portions of three structural domains, i.e., the active South Iceland Seismic Zone (SISZ), considered to be a young transform zone, the adjacent Hreppar Microplate (HMP), and the Western Rift Zone (WRZ) also called the Reykjanes-Langjökull Rift Zone (Figure $1(\mathrm{~b})$ ). The HMP is bounded by the SISZ, but also by the receding WRZ and the propagating Eastern Rift Zone (ERZ).

Since [4] identified that spreading is accommodated by both divergence along rift/ridges, as reflected in magnetic anomalies [5], and shear motion along transform zones, identified on the basis of earthquakes [6] [7], details have emerged regarding the complexities of these apparently simple linear boundaries. The complexities result from changes in spreading, propagation or failure of rift segments, instability of transform zones, and formation of microplates. Initially, the processes of diverging plate boundaries in both continental and oceanic contexts were mostly reported from fast spreading centres in East Pacific, the San Andreas Fault, and the East African Rifts/Gulf of Aden. A great portion of those findings comes from offshore gravity, paleomagnetism, bathymetry, regional seismic data and analogue modelling. Therefore, observations from rare outcrops of oceanic crust in slow-spreading centres provide first hand insights into the tectonics of these plate boundaries, which ultimately control basin formation and sedimentation, block compartmentalisation, magmatism and fluid flow in fractured hydrocarbon and geothermal reservoirs, as well as related metalliferous deposits.

This paper presents extensive structural observations from a 10-year geological investigation in varied regional structural domains of different characteristics and kinematics in South Iceland. The investigations were carried out for the National Power Company (Landsvirkjun), as a means to assess the seismic risk for the construction of three hydro power plants. This paper is organised as follows: 1) It first gives the key features of the deformation associated with diverging plate boundaries, as a common frame. 2) Then it presents the methods and data, followed by our observations and interpretations. 3) Finally, it discusses the significance of the interpreted deformation with respect to the regional structures, including similarities and differences with selected key tectonic models. The steps undertaken in the investigations are examples of thorough exploration methods that range from aerial images to outcrops, from $\mathrm{cm}$ to tens of $\mathrm{km}$ in scale, and from local to regional multidisciplinary interpretations. Not only does this contribution bring new insights into the geology of Iceland, but the methods 


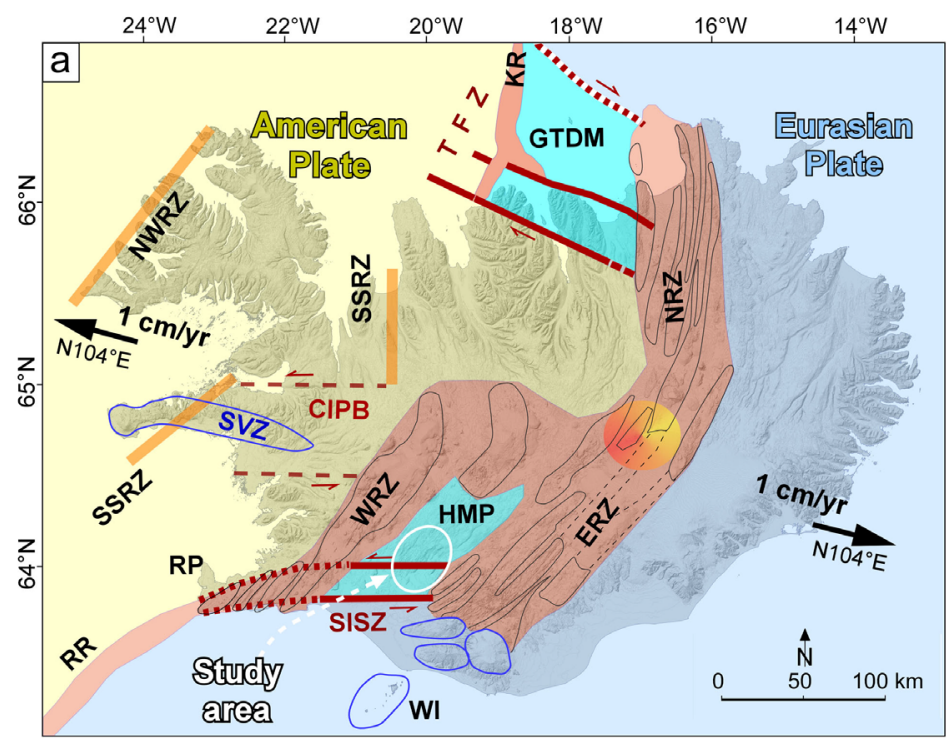

Active plate boundaries/Microplates:

KR: Kolbeinsey Ridge; NRZ: Northern Rift Zone; ERZ: Eastern Rift Zone; WRZ: Western Rift Zone (or Reykjanes-Langjökull Rift Zone) TFZ: Tjörnes Fracture Zone; SISZ: South Iceland Seismic Zone; RP: Reykjanes Peninsula; RR: Reykjanes Ridge; HMP: Hreppar Microplate; GTDM: Grímsey-Tjörnes-Dalvík Microplate;

Extinct Tertiary plate boundaries:

NWRZ: Northwest Rift Zone; SSRZ: Snæfellsnes-Skagi Rift Zone;

CIPB: Central Iceland plate boundary

Quaternary intra-plate: SVZ: Snæfellsnes Volcanic Zone

Other: WI: Westmann Islands and Surtsey

Active rift
Rift fissure swarm
Active transform zone
Oblique rift
Dextral motion

Microplate

Extinct rift segment

Possible extinct transform zone

Quaternary-Holocene off-rift volcanism

Centre of hotspot

Plate spreading direction

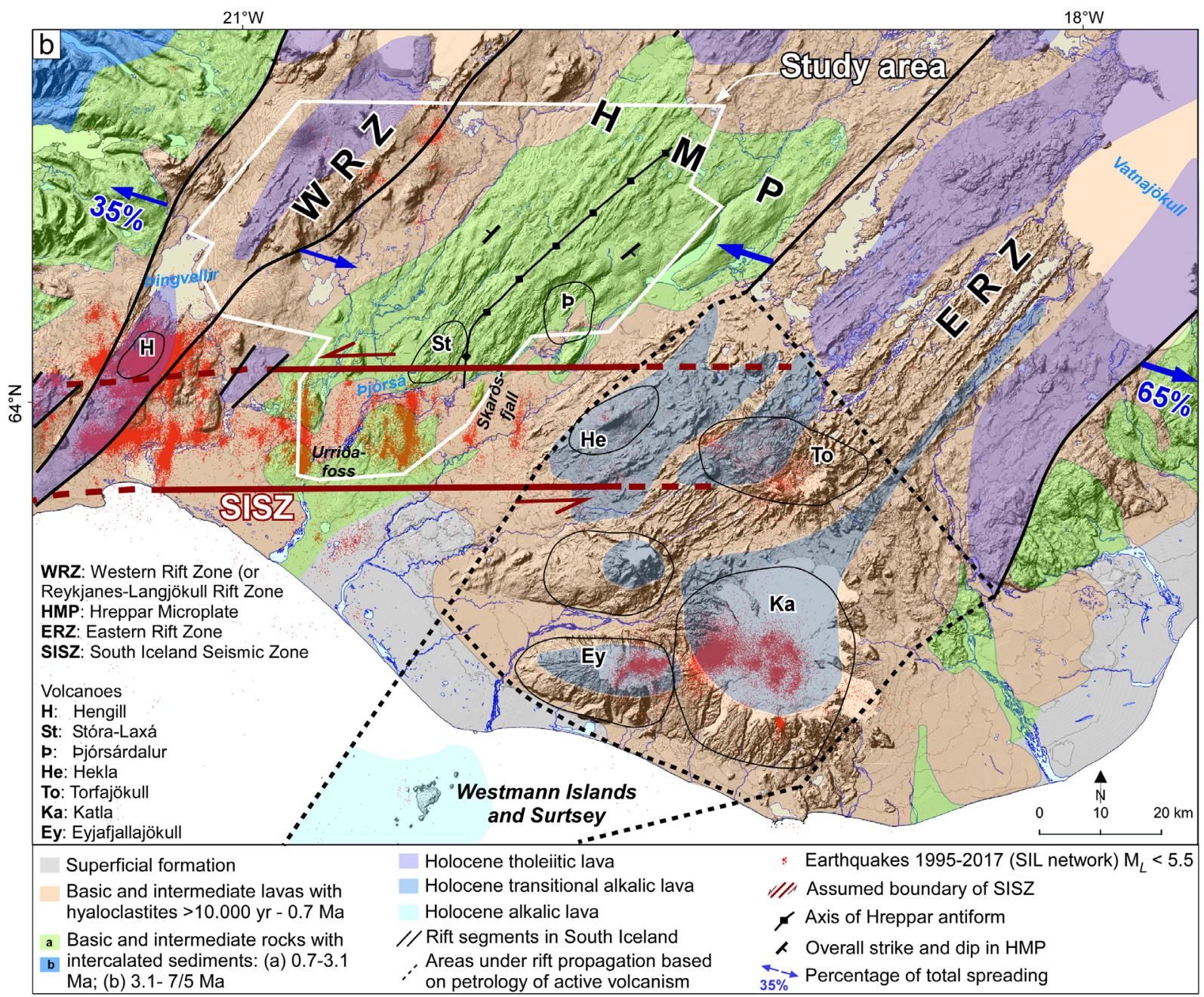

Figure 1. Geological settings of Iceland and the study area. (a) Active and extinct plate boundaries and microplates in Iceland (modified from [55]); (b) Main geological elements of the study area. Fissure swarms and intraplate volcanism on (a), and the geology and tectonics on (b) are from [122], the petrology of Holocene and Late Pleistocene volcanic systems is from [109], and the earthquakes are from the SIL network of the Icelandic Meteorological Institute (IMO). The rate of spreading is from [121]. 
and results in this case study will also benefit exploration and resource management at other diverging oceanic plate boundaries.

\section{Geodynamics of Diverging Plate Boundaries}

As oblique rifting is absent in the study area, an overview of the key features associated with rift/ridges, transform zones, and microplates is presented below.

- Continental rifts and oceanic ridges trend orthogonal to spreading. From initial continental break-up, extension is accommodated by rift boundary normal faults, but intra-rift complexities appear during rift evolution with half-grabens, subsided central grabens/axial valleys, uplifted rift shoulders, rotated fault blocks and detachments [8] [9], as well as ridge segmentation [10] and ridge instability [11] [12]. During their evolution as slow ( 20 $\mathrm{mm} / \mathrm{yr}$ ) or fast $(80-145 \mathrm{~mm} / \mathrm{yr})$ spreading centres [3], the crust thins out under stretching, leading to volcanism [1] and the build-up of the oceanic crust by magma injections from the mantle into the axes of rift/ridge segments. Acidic and basaltic magmatism appears either as eruptions in central volcanoes and from fissures, or as injections of deeper sills and dykes in and adjacent to rifts/ridges. Seismic swarms accompany rifting episodes and magma injections [13] [14] [15]. High temperature geothermal activity is present in rifts onland, and as hydrothermal vents and black smokers along ridges offshore. The geometry, the rate and direction of spreading are reflected in magnetic chrons, which are the basis for modelling of the rifts and their instabilities [11] [16].

- Transform zones offset two ridge segments. Their sense of horizontal motion differs from Anderson's fault theory as transform zones are parallel to the relative plate displacement and accommodate the spreading [4] [17]. At oceanic stages, the transform zones separate the oceanic lithospheres [18], but their origin is debatable. They are seen initiating as crustal weaknesses during continental break-up [4] [19] and are continuously active past the oceanisation stage [20], appearing only after oceanic accretion has started [21] [22], predating oceanic accretion [23], or developing after ridge propagation stops [24]. The crust is neither built nor destroyed, except in leaky transform zones where volcanism produces locally new crust under oblique-extension [25] [26] or magma is injected as deep dykes and sills [27]. The depth of earthquakes in transform zones is generally $10-15 \mathrm{~km}$ in the brittle crust, but limited by the $600^{\circ} \mathrm{C}$ isotherm [28]. While some consider the crust to be cold in transform zones [29] [30], others predict an elevated heat flow [31] [32]. Sea water contributes to serpentinisation, and along with hydrothermal fluid flow, they change the total stress distribution [33].

High seismicity due to rupture of strike- and oblique-slip faults, and internal bookshelf tectonics with counter-clockwise block rotation on parallel strike-slips [34] [35] [36] are two key features within transform zones. However, the spreading and slip rates, the length of the transform zones, as well as 
the presence of a viscous layer determine the geometry and structural pattern of these shear zones [37]. Oceanic transform zones are knife cut valleys of $\sim 10$ to $30 \mathrm{~km}$ width in slow spreading ridges, and $>100 \mathrm{~km}$ in fast spreading centres [9] [24], with inner and outer bends at the intersections with ridges, and offsets ranging from $50 \mathrm{~km}$ to $>350 \mathrm{~km}$ [29] [38]. Narrow transform zones are controlled by parallel boundary and internal faults, while the overall shear motion of wider transform zones is accommodated mostly by secondary faults oblique to the zones [9] [37] [39]. At a young stage, the internal oblique faults present en échelon arrangements above deeper strike-slip faults [40] [41] [42]. Continental transform zones are sharp strike-slip faults with internal stepovers and splays [43] [44] [45], restraining and releasing bends [44] [46] [47] [48], pull-apart basins and rhomb-grabens [25] [46] [49] [50] [51], as well as small en échelon basins [52]. Some of these internal structures are common in both oceanic transform zones [53] [54] [55], and in transfer zones that connect continental rift segments [56] [57]. Transfer zones equally undergo seismicity and local magmatism [58] [59] [60]. In all of these contexts, partitioning of the damage zones of strike-slips faults [8] [61] [62] [63] [64] controls the fluid flow and permeability along individual structures.

- Transform zones are generally orthogonal to rift/ridge segments but their angular relation is an important feature. When initiating from crustal weaknesses, particularly in leaky transform zones, a complex transtensional Riedel shear zone develops at an angle of $\sim 73^{\circ}$ to the rift segment, but later rotates to the stable orthogonal configuration at an oceanic stage [37] [65] [66].

- Plate boundaries become unstable due to changes in the rate and direction of plate motion, and readjust through overlapping rifts, rift-jumps, migrating and rotating transform zones, as well as the formation and rotation of microplates [24] [35] [36] [67] [68]. When spreading is accommodated by overlapping rifts/ridges, especially near hotspots, the propagating segment lengthens along strike, while the active length of the receding segment shortens and it eventually fails [11] [69] [70]. Spreading and propagation cause the V-shaped geometry of the magnetic chrons and the pseudofaults on each side of the propagator, a transfer of narrow lithospheric block from one plate to another by rift-jump, and a migration of the transform zone [11] [12] [71]. Hotspots produce an elevated topography, sometimes above sea level [72], thus facilitating the propagation of rifts/ridges away from the hotspot [68] [73]. However, examples to the contrary also exist where ridges have a tendency to propagate towards hotspots and halt there [74].

- Overlapping rifts generally display inward bends at the tips of propagating segments, with complexities in the linkage area [75]. Typically, in slow spreading centres where a major transform fault is absent in the linkage area, extension is accommodated by bookshelf faulting on, and a horizontal rotation of small blocks along strike-slip faults parallel to rift/ridge segments [76] [77] [78] [79]. In fast oceanic spreading, some overlap areas of propagating/receding ridges are broad "non-transform" shear zones. There, seismicity 
occurs on pre-existing faults of the failed rifts, which were tectonically rotated into new oblique trends [68]. In a fast spreading context, when the overlap area becomes too wide, a microplate develops by a transfer of lithosphere from one plate to another, and rotates around a vertical axis to accommodate independently the spreading [67] [80]. The amount of rotation is a function of the rates of spreading and propagation [81]. Microplate rotation produces an oblique seafloor, expressed as a fan-shaped pattern in magnetic chrons or rotated bathymetric fabrics [68]. Additional deformation appears in the rotated microplate if adjacent to a transform zone. Magnetic chrons would show seafloor rotation in the microplate if the deformation is accomplished by bookshelf faulting and internal rotation [35]. But no rotation occurs if the deformation is accomplished by transform-parallel shears [82].

The study area contains similar structural domains. Therefore, the outcrop observations and interpretations in this paper give a means to check which of the processes described above have taken place in South Iceland. As diverging plate boundaries host both the geothermal fields and the petroleum systems, the deformation at rifts, transform zones and microplates have direct implications for both resources. However, the above processes occur over geological time-scales, of the order of million years, and are not fully detectable by short-term present-day crustal deformation measurements.

\section{Geological Settings of Iceland and the Study Area}

With a spreading rate of $20 \mathrm{~mm} / \mathrm{yr}$ [83], Iceland is a slow spreading centre, which displays active and extinct plate boundaries since the Tertiary (Figure 1(a)), as well as Quaternary intraplate earthquakes [84] and volcanism [85] [86]. The active rift segments are the Northern Rift Zone (NRZ) and the Eastern Rift Zone (ERZ), as well as the Western Rift Zone (WRZ) (Figure 1(a)). The active transform zones, initially identified from earthquakes [6] [87] [88], are the Tjörnes Fracture Zone (TFZ) and the South Iceland Seismic Zone (SISZ). Oblique rifting occurs in the TFZ [89], and on the Reykjanes Peninsula [90] before joining the Reykjanes Ridge (RR) offshore.

Relocations of rifts (rift jumps) since $24 \mathrm{Ma}$ [91] have left a series of parallel extinct rift segments that stretch from the centre of the hotspot towards the northwest (Figure 1(a)). Opinions diverge on many aspects of rifting and transform faulting. The Northwest Rift Zone, active from 24 to $15 \mathrm{Ma}$ [92], shifted to the Snæfellsnes-Skagi Rift at $15 \mathrm{Ma}$ [93] [94], and from the Snæfellsnes Rift Zone (SRZ) to the WRZ at 5/7 Ma [95]. These two latter were considered to be overlapping rifts, with the SRZ receding and the WRZ propagating southwestward until the latter reached its present geometry [93] [96]. Some consider an eastward jump of the Skagi Rift Zone to the NRZ at about $12 \mathrm{Ma}$ [94] [97], or 8 - 8.5 $\mathrm{Ma}$ [98]. However, others propose an active predecessor to the NRZ located to its east, which jumped westward at $12 \mathrm{Ma}$ and at 6/7 Ma, stabilised to its present location and propagated southward to the ERZ [99] [100]. An E-W transform zone around $65^{\circ} \mathrm{N}$ has been speculated during Tertiary rifting, connecting the 
SRZ, SKR and NRZ [93] [94] [100] [101], with a dextral [102] or a sinistral motion and an internal deformation similar to the SISZ [103]. During plate boundary reorganisations, crustal blocks have been transferred from one plate to another, resulting in the formation of the Grímsey-Tjörnes-Dalvík and the Hreppar Microplates. Many areas were subject to uplift and subsidence, unconformities, flexuring, major block rotation and intense fracturing [53] [93] [102] [104] [105]. Despite past and present overlapping rifts, the V-shaped geometry is demonstrated only offshore along the RR [71], although that geometry does not appear in some bathymetric/paleomagnetic studies along the RR [106] [107].

Rift segments consist of fissure swarms of parallel normal faults, eruptive fissures and dykes emitting basaltic and intermediate lavas, as well as calderas hosting acidic rocks [97] [108] [109]. These swarms strike N-S in the NRZ and NNE/NE in the WRZ and ERZ (Figure 1(a)). Reworked, glacio-lacustrine or local marine sediments are intercalated in the series spanning $15 \mathrm{Ma}$, while subglacial hyaloclastite ridges are within formations of $<0.7 \mathrm{Ma}$ age. The oceanic crust is eroded down to $1.5 \mathrm{~km}$ in Tertiary rift flanks, and down to $0.7 \mathrm{~km}$ in Hreppar [110] [111] [112]). Both of the active transform segments undergo continuous earthquakes, as large as $M_{L} 6$ - 7 [113] due to ruptures of strike- and oblique-slip faults [83] [114] [115] [116] [117]. High temperature geothermal fields $\left(200^{\circ} \mathrm{C}-300^{\circ} \mathrm{C}\right)$ are at the intersection of rift and transform segments [118] [119] and medium to low-temperature fields $\left(<150^{\circ} \mathrm{C} / \mathrm{km}\right)$ are common off rifts. Both types of resources are fracture-controlled.

In the study area, the main structural elements of the WRZ, ERZ, HMP, and SISZ are:

- The late Pleistocene-Holocene lavas are tholeiitic basalt within the overlapping ERZ and WRZ, but transitional alkalic and alkalic at the southwestern tip of the ERZ (Figure 1(b)). Furthermore, the results of continuous GPS measurements indicate a higher horizontal velocity east of the ERZ, holding the American Plate fixed [120]. This is in agreement with the estimation that only up to $35 \%$ of the total spreading rate takes place along the WRZ [121]) and 65\% along the ERZ (Figure 1(b)). The petrology and the spreading rate indicate a southwestward propagation of the ERZ.

- The HMP, which formed at the plate boundary and shifted away, is caught between the WRZ, ERZ and SISZ, but its northern boundary is poorly defined. The trace of the suspected Tertiary transform zone at around $65^{\circ} \mathrm{N}$ coincides with the northern boundary of this microplate. However, that boundary in central Iceland presently displays an active tholeiitic volcanism and fissure swarms similar to rifts (Figure 1(a)). The fracture pattern consists mostly of NNE rift-parallel faults and dykes, although ENE and WNW sets have been also identified [122]. Another structure of the HMP is an antiform, labelled as an "anticline" in the literature. Its proposed axis is mostly NE, parallel to the rifts, but bends to N-S in the south adjacent to the SISZ [122]. Such a structure does not result from shortening due to compression. It forms due to loading and extension associated with rifting [123] [124], as 
the lava pile tilts first towards the active rift zone (WRZ), then towards the new rift (ERZ).

- The study area is covered by the 3.4 - 0.7 Ma Hreppar formation, which extends from the HMP into the SISZ [96]. Those series consist of basaltic lavas and hyaloclastites, with acidic rocks limited to Stóra-Laxá (SLCV) and pjórsárdalur central volcanoes (PCV) [125], and thin sills [126]. The 8,600-yrs old postglacial bjórsá lava covers the Hreppar Formation in places and is the longest Holocene tholeiitic lava in Iceland, with some $22 \mathrm{~m}$ thickness and $\sim 25 \mathrm{~km}^{3}$ volume [127]. Superficial formations overlie both the Hreppar formations and the pjórsá lava. Although some models predict elevated temperature and thin lithosphere at depth under transform zones [31] [32], regional tomography in South Iceland shows that the crust is thin in the WRZ, and thicker $(20-24 \mathrm{~km})$ under the SISZ until its intersection with the ERZ near the centre of the hotspot [128] [129]. Temperature gradients also indicate a cold crust $\left(50^{\circ} \mathrm{C}-150^{\circ} \mathrm{C} / \mathrm{km}\right)$ in South Iceland, with the highest values being near the rift segments [130].

- The SISZ, connecting the WRZ and ERZ, is proposed as an overall E-W seismic zone with a sinistral motion and a constant slip rate of $19 \pm 1 \mathrm{~mm} / \mathrm{yr}$ [83] [116]. Its width is $\sim 25 \mathrm{~km}$, corresponding to the extent of the present-day earthquakes, and its length is considered $80 \mathrm{~km}$ between Hengill and Hekla. However, the results of detailed GPS measurements indicate that the SISZ could be longer, extending to Torfajökull farther east [131]. Opinions also diverge on the overall trend of this transform zone as some suggest it to strike WNW [88] [100] [132]. Regardless of its trend, the SISZ is thought to be a nascent transform zone. In the absence of boundary faults, the sinistral motion of this zone is achieved by periodic earthquakes up to $\mathrm{M}_{\mathrm{L}}$ 7, generally shallow, but as deep as $10 \mathrm{~km}$ such as in the 2008 earthquake doublet [116]. Earthquakes occur primarily on parallel internal N-S dextral faults, with an anticlockwise block rotation or bookshelf tectonics [83] [133], causing wide damage zones that extend into the HMP [134]. Outcrop mapping [126], and relative locations [135] [136] [137], however, show ruptures on additional albeit less frequent strike-slip fault sets striking ENE, WNW/NW and E-W, indicating that the SISZ is a Riedel shear zone [138]. The ENE sinistral and the N-S dextral faults form the main conjugate source faults of earthquakes. The N-S faults can reach up to $20-25 \mathrm{~km}$ in length and their surface expression is left-stepping en échelon sink-holes, open fractures and push-ups. They are nearly vertical at depth [139], and have a horizontal offset up to $2 \mathrm{~m}$ [116] and dip-slips $<1.5 \mathrm{~m}$ in a single earthquake [117]. The ENE sinistral faults appear as shorter segments at the surface and have a right-stepping en échelon arrangement [140] [141].

\section{Observations}

\subsection{Methods and Data}

The data and methods presented in this study address various scales of tectonic 
observations, reflecting rifting and transform faulting in formations of different ages. In the following chapters:

- We first present a lineament map made from aerial photographs that covers the WRZ, HMP, and SISZ for an overview of the regional fracture pattern (Figure 1(b) and Figure 2).

- The geological and tectonic observations are then presented from four selected outcrops, in the oceanic crust that spans 3.4 Ma to Holocene $(<8,600$ yrs). The observations come from classical mapping of stratigraphy and major faults and dykes in the basement rocks, the strikes and dips of the series (Figure 3), and the measurements of associated secondary fractures. Further outcrop mapping of the Holocene surface ruptures and leakages of cold and warm water were made with a hand-held GPS, as well as additional measurements of joints in the Holocene formations. Their qualitative and quantitative analyses are discussed to reflect the status of tectonics in the basement and their reactivation during the present-day earthquakes related to transform faulting in the SISZ (Figures 4-13).

- The observed outcrop deformation is interpreted in Chapter 5 (Figure $14)$.

- As the results have regional significance, the deformation is further interpreted in Chapter 6 with respect to selected common processes of diverging plate boundaries. For this, a morphostructural analysis is carried out using topographic cross-sections through the rift segments, the HMP and the SISZ, to address the geometry and the boundary of the SISZ (Figure 15). Finally, the regional lineament map, as well as the results of the latest available continuous GPS measurements, are interpreted to better understand the longand short-term deformation of the HMP (Figure 16 and Figure 17).

\subsection{Regional Tectonic Lineaments}

About 20,127 segments were observed on 220 monochrome non-rectified aerial photographs at the scale of $\sim 1: 35,000$ (Figure 2(a)). The photographs are, however, 110 stereographic pairs and allow observations of the terrain in relief to help the interpretation of the lineaments and their relation to topography. The observed structures were then transferred onto a single topographic map in GIS and rectified to minimise the distortion. After this processing, the estimated error in the location of the lineaments on Figure 2(a) is maximum $10 \mathrm{~m}$, locally. The lineaments cover an area of $\sim 3500 \mathrm{~km}^{2}$, and cut the upper Tertiary bedrocks to late Holocene lavas in the WRZ, HMP and SISZ. As the map was prepared to provide a regional overview of the fracture pattern, the structures are drawn as undifferentiated faults, dykes, and prominent joints, irrespective of the magnitude of fault displacement, thickness of dykes, and whether a segment is major or minor.

The main features of the fracture distribution and frequency at the regional scale are as follows: 


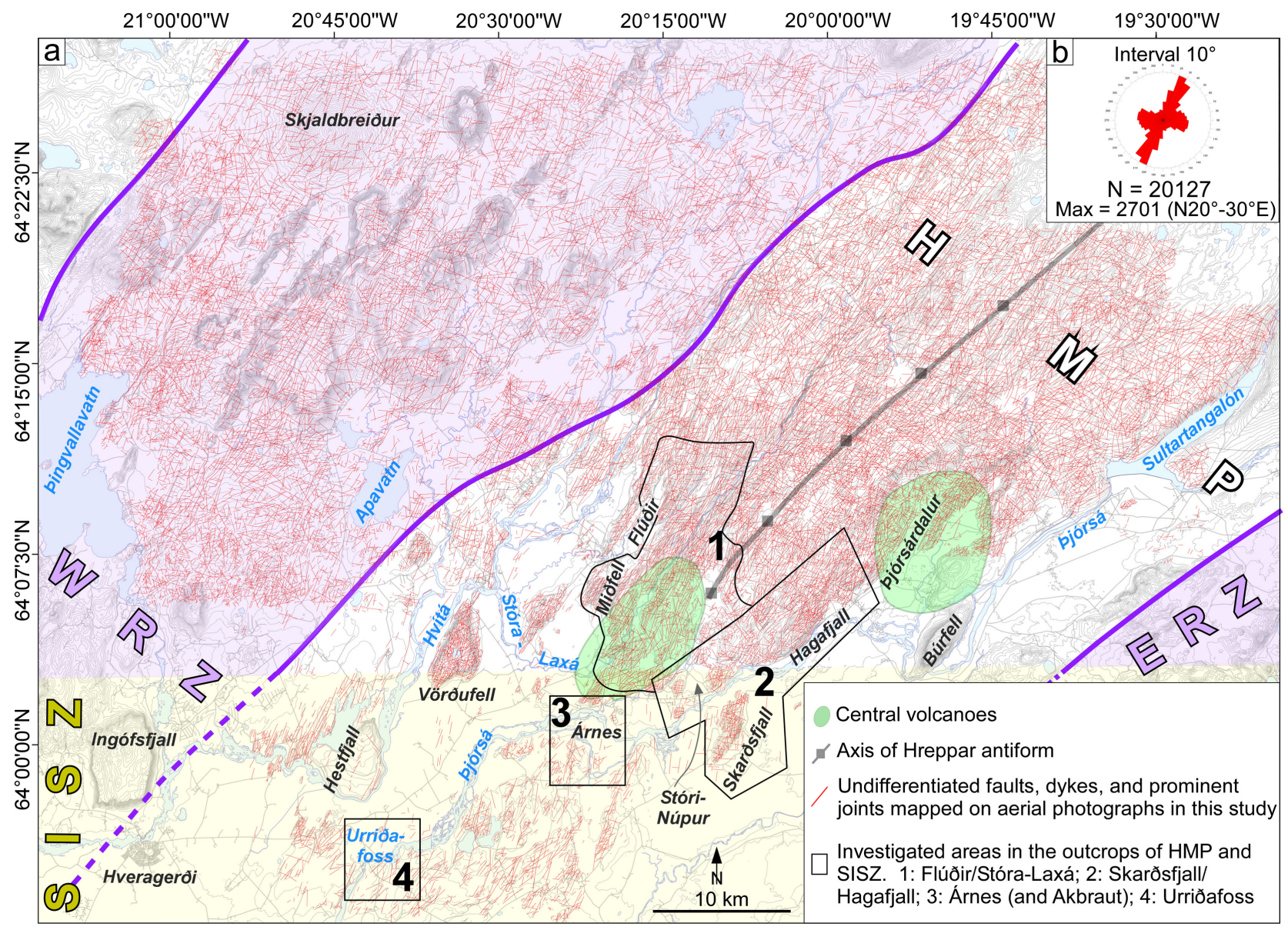

Figure 2. Tectonic lineament map of South Iceland showing the regional fracture pattern mapped from aerial images, and the locations of Areas 1 to 4 investigated in outcrops. (a) Undifferentiated fractures in the WRZ, the HMP and the SISZ from aerial photographs (modified from [126]). Base topographic map from the National Land Survey of Iceland. Plate boundaries and central volcanoes are the same as on Figure 1(b); (b) Rose diagram of the mapped fracture pattern with $10^{\circ}$ intervals.

- The statistical analysis of the entire fracture population was carried out using a $10^{\circ}$ interval in the strikes of the lineaments. Results show that the most frequent fractures strike $\mathrm{N} 20^{\circ}-\mathrm{N} 30^{\circ} \mathrm{E}$, followed by another peak at $\mathrm{N} 90^{\circ}$ $\mathrm{N} 100^{\circ} \mathrm{E}$, although fractures with other strikes are also widely present (Figure 2(b)).

- The visual inspection of the lineament map in the three structural domains indicates that fracturing is denser in the older Hreppar formation of the HMP to the east of the antiform, and in a few similar outcrops in the SISZ. But it is less dense in the Pleistocene-Holocene formations of the WRZ, and least dense in the SISZ where Pjórsá lava covers the older Hreppar formation.

- There is also a continuity between the widely striking fractures in the WRZ and the HMP, while fractures striking northerly and ENE are more prominent in the SISZ. Although the boundary of the SISZ is more complex in detail, the pjórsá River acts as a general limit between the HMP and the SISZ. Another feature on the lineament map is that some of the fractures continue from the SISZ into the HMP. 


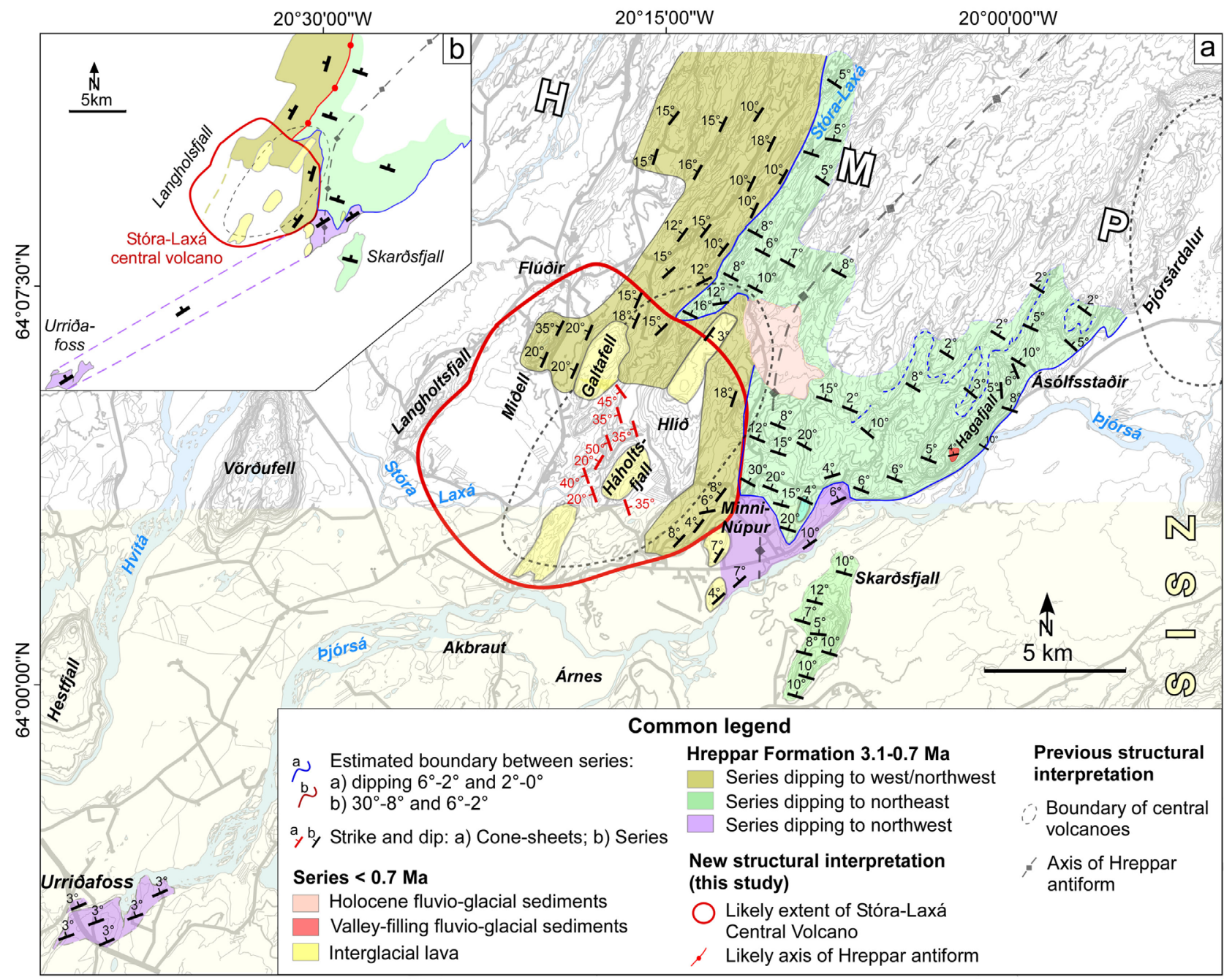

Figure 3. The main stratigraphic units in the outcrops of Area 1 to the south of the HMP and in the SISZ. (a) Three overall series in the Hreppar formation, identified based on their dips to the northwest, the northeast and the west/northwest, along with the cone-sheets measured in the SLCV [126]; (b) A simplified figure showing the structural interpretation of the extent of the SLCV and the axis of the Hreppar antiform suggested in this study compared to previous interpretations by [122].

- Whether in the HMP or in the SISZ, the Hreppar formation has been generated partly in the WRZ and partly in the ERZ, with some of the outcrops studied here still at or near the rift segments before shifting away. Therefore, the NNE rift-parallel extensional fractures are expected to dominate the tectonic pattern in these older bedrocks. Although fracture types per set will be discussed in the following chapters with outcrop data, one observation can be made based on the strike of the rift-parallel fractures. The strike-range of these purely extensional fractures is $\mathrm{N} 21^{\circ}-\mathrm{N} 40^{\circ} \mathrm{E}$ within the WRZ. However, this strike-range represents only $23 \%$ of the total fracture population on the lineament map, indicating that non rift-parallel fractures are indeed more frequent. This frequency is in agreement with results of studies carried out in other areas of Iceland subject to past and present rifting and transform faulting [55] [142] [143] [144]. 


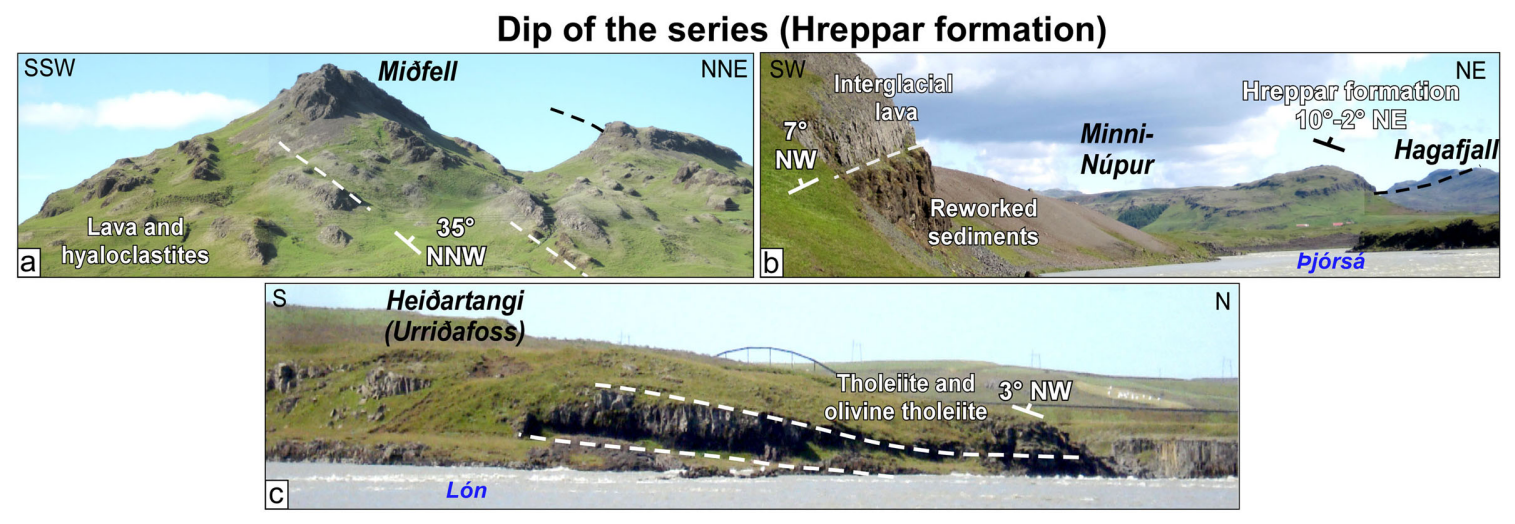

Stratigraphy: Hreppar formation (3.4-0.7 Ma)
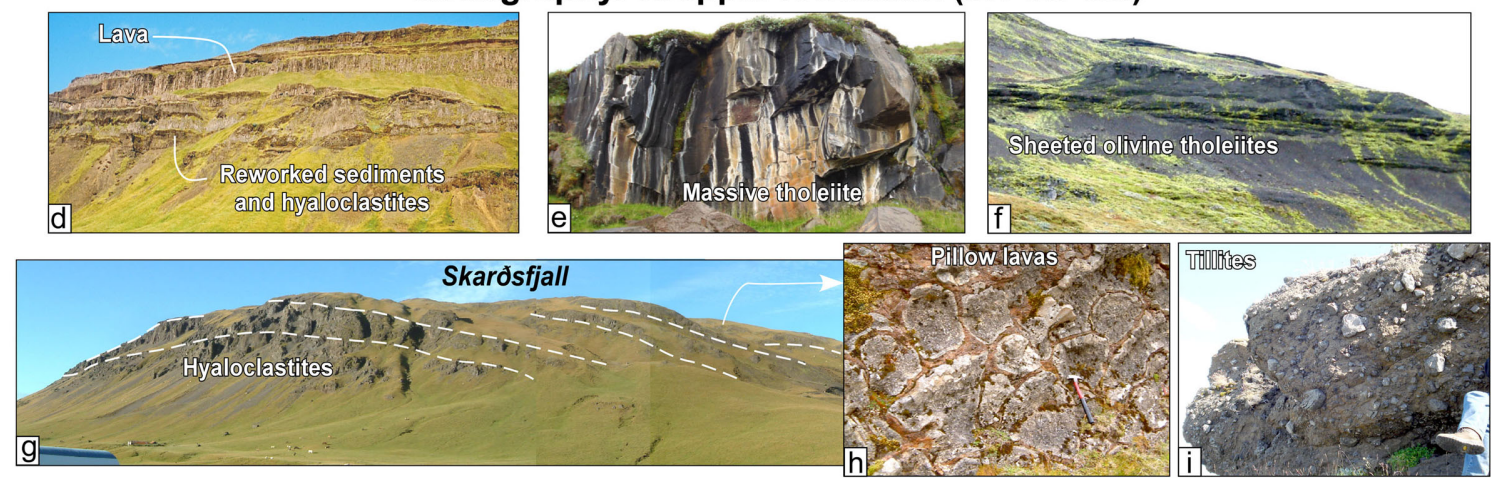

Stratigraphy: younger series ( $<0.7 \mathrm{Ma})$
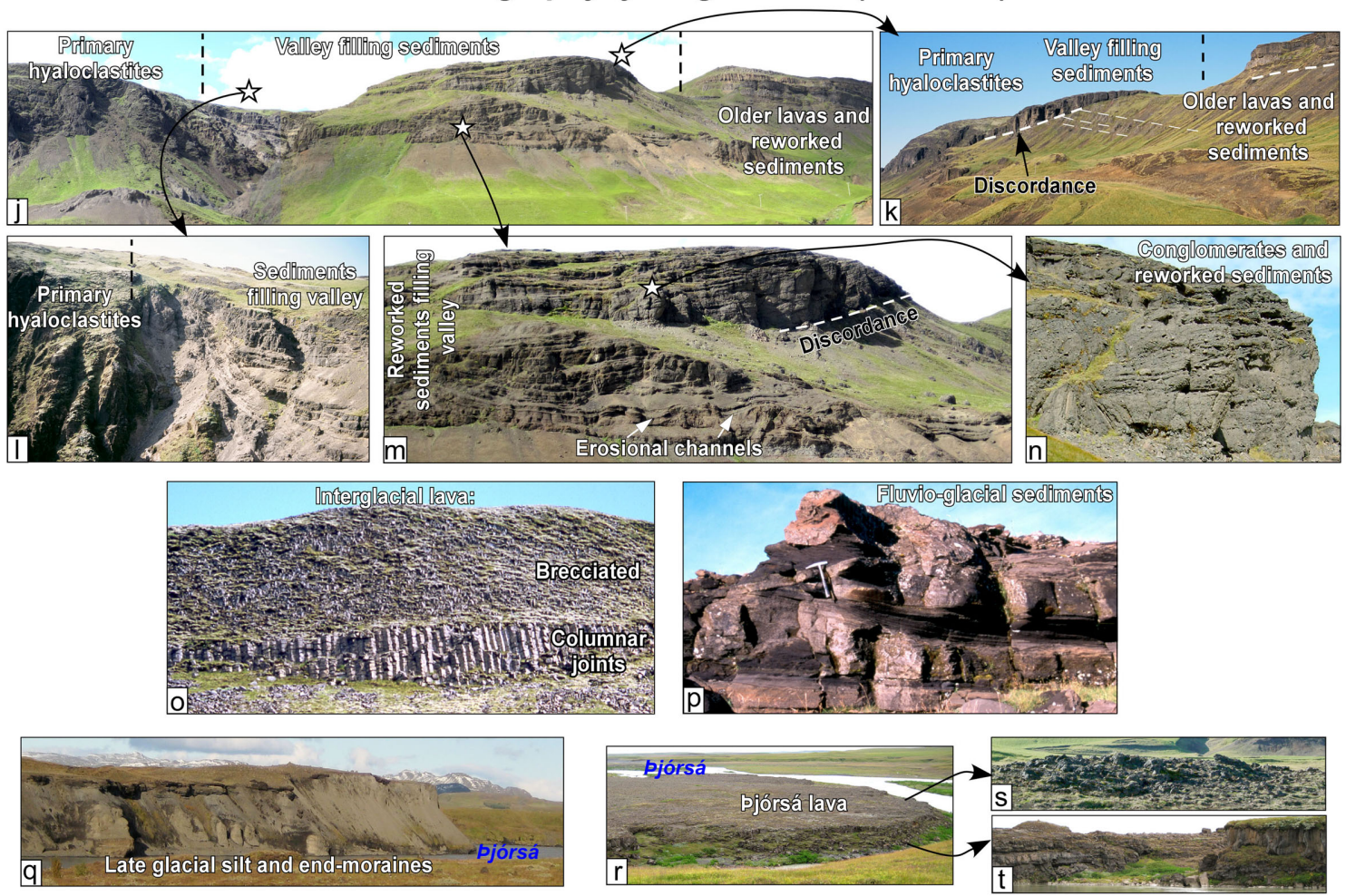

Figure 4. Outcrop photographs showing the stratigraphy. (a) to (c) Examples of dips of the series, ranging from $35^{\circ}$ to $3^{\circ}$; (d) to (h) Mapped lavas, reworked sediments, massive and sheeted tholeiite, primary hyaloclastites and pillow lavas, as well as tillites belonging to the Hreppar formation; ( $j$ ) to (p) Valley filling sediments, interglacial columnar-jointed lavas, and fluvio-glacial sediments $<0.7 \mathrm{Ma}$; (q) to (t) Late glacial silt, end moraines, and the Holocene Pjórsá lava. 


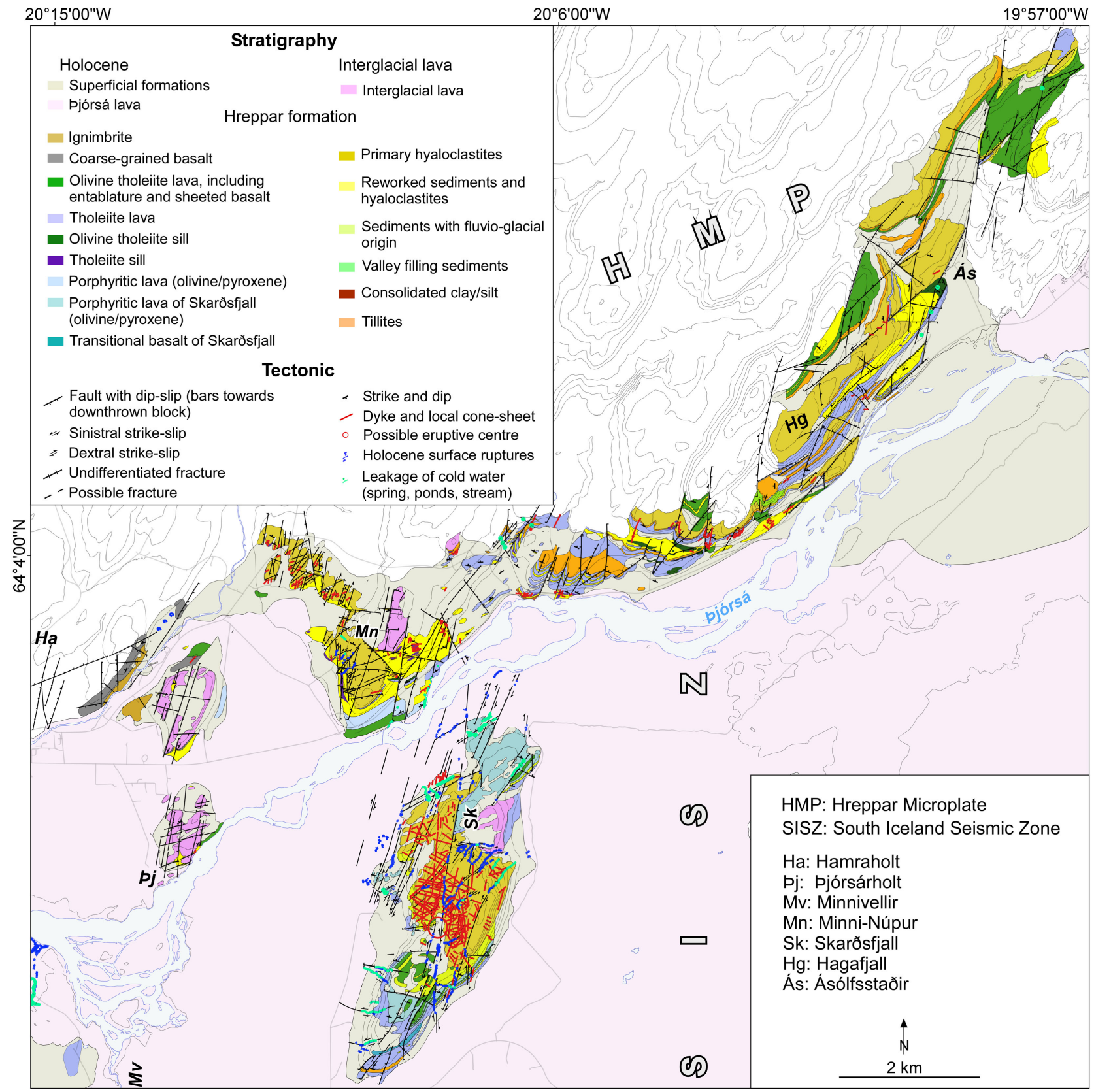

Figure 5. Geology and tectonics of Area 2 mapped in outcrops at the site of the Hvammsvirkjun power plant.

\subsection{Outcrop Geology}

Four selected outcrops (Areas 1 to 4 on Figure 2(a)) were investigated for detailed information because of their relevance for the planned hydro power plants. Area 1 is Flúðir/Stóra-Laxá, while areas 2 to 4 covering Skarðsfjall/Hagafjall, Árnes/Akbraut, and Urriðafoss (Figure 5 and Figure 6) are directly at the sites of Hvammsvirkjun, Holtavirkjun, and Urriðafossvirkjun power plants. Results of these field investigations are presented below.

\subsubsection{Regional Strikes and Dips}

The series mapped in the four areas consist of the Hreppar formation (3.4 - 0.7 Ma), 


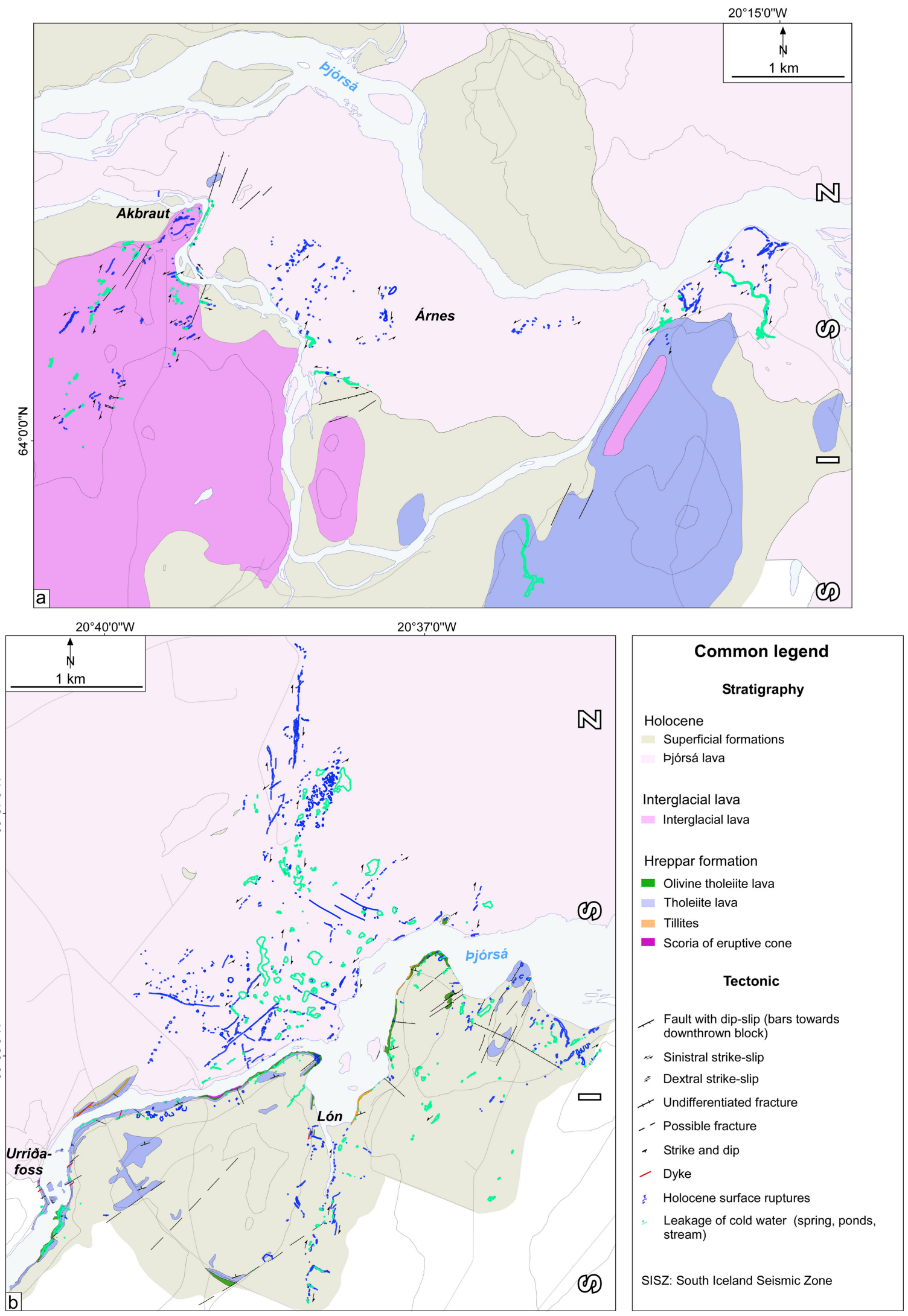

Figure 6. Geology and tectonics of Areas 3 and 4 mapped in outcrops. (a) At the sites of the Holtavirkjun; and (b) the Urriðafossvirkjun power plants. 

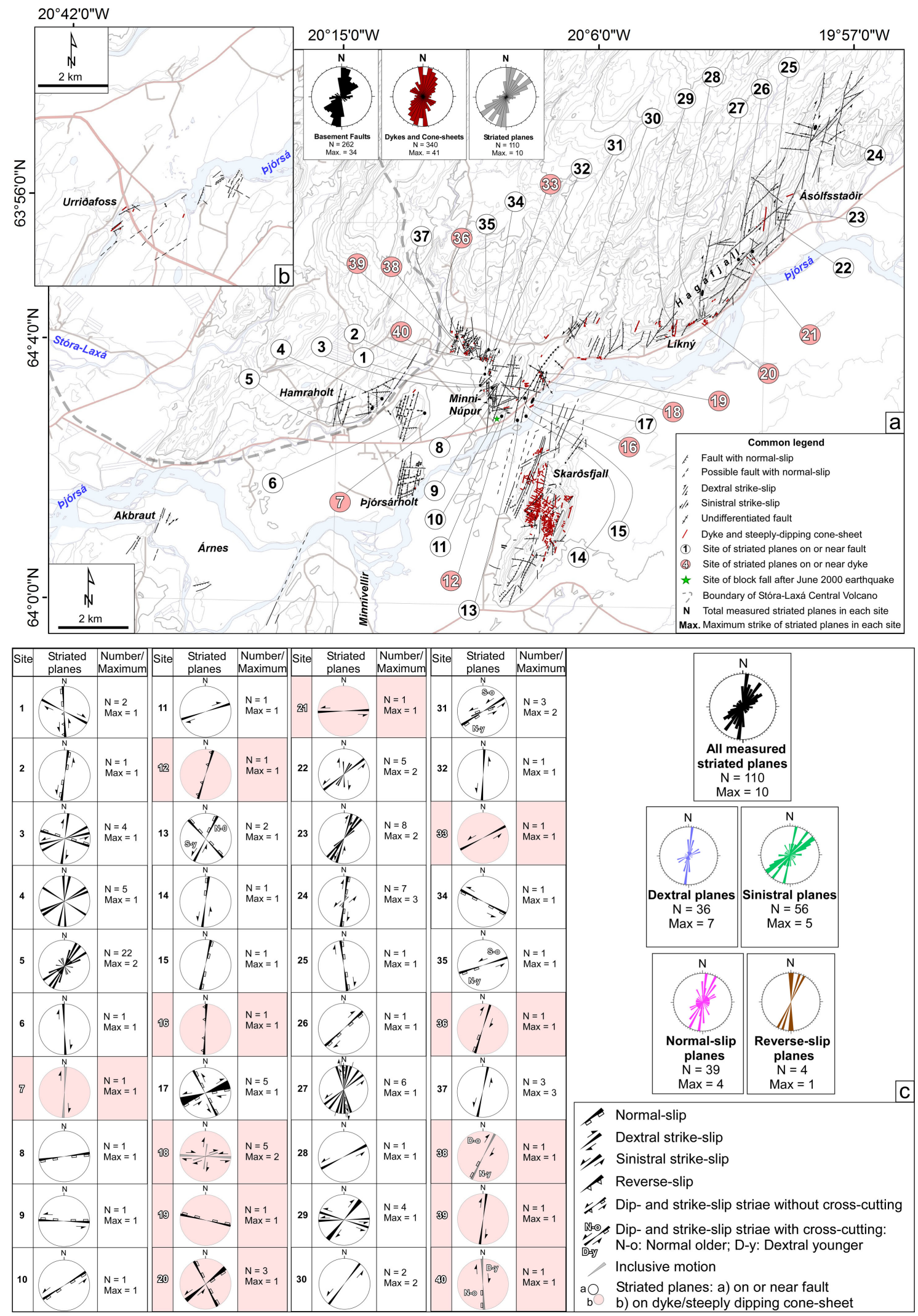

Figure 7. Faults, dykes and striated planes. (a) and (b) The mapped faults and dykes in Areas 2 to 4 , and locations of the measured striated planes. The rose diagrams show $10^{\circ}$ intervals; (c) The table summarising the motions of major fractures, along with cross-cutting striae. Rose diagrams show $5^{\circ}$ intervals and are coloured to illustrate the motions per sets. 

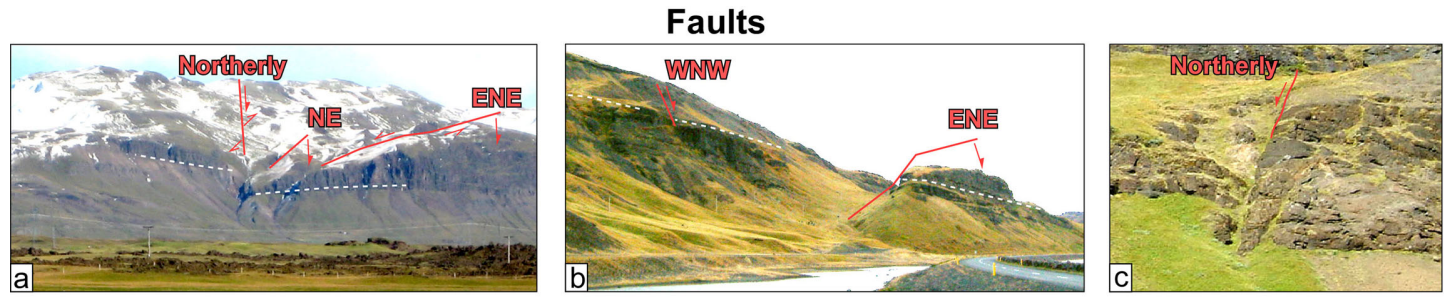

Dykes, sills, cone-sheets
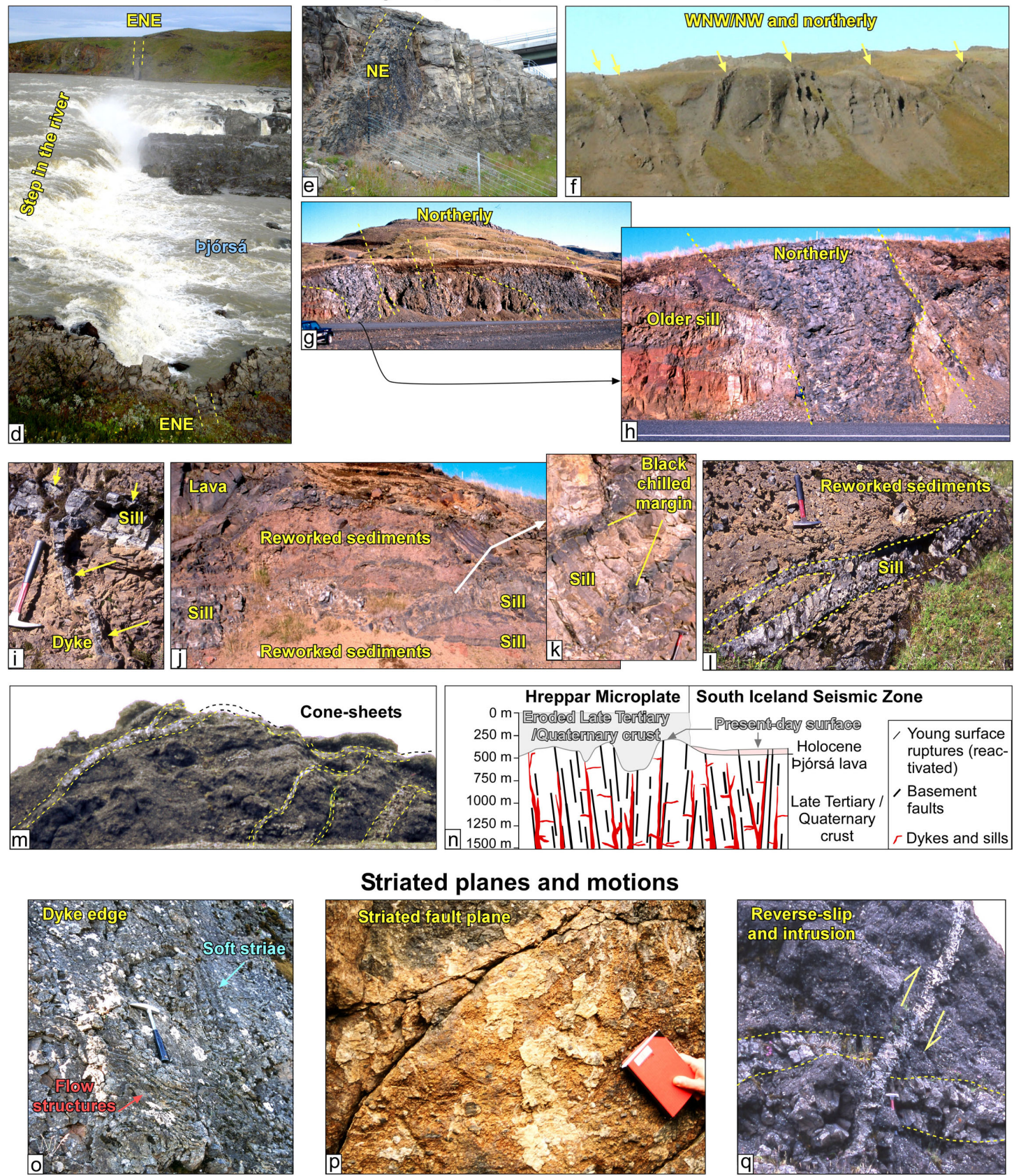

Figure 8. Outcrop photographs of basement faults, intrusions and kinematic indicators. (a) to (c) Examples of faults with different strikes and magnitude of dip-slips; (d) to (m) Examples of dykes with various geometry, strikes and thicknesses, as well as sills and cone-sheets; (n) A schematic cross-section down to $1500 \mathrm{~m}$ depth showing the distribution of faults and intrusions in the oceanic crust; (o) Soft striae and flow structures at a dyke's edge; (p) An example of a striated plane; (q) An example of reverse-slip associated with a dyke. 

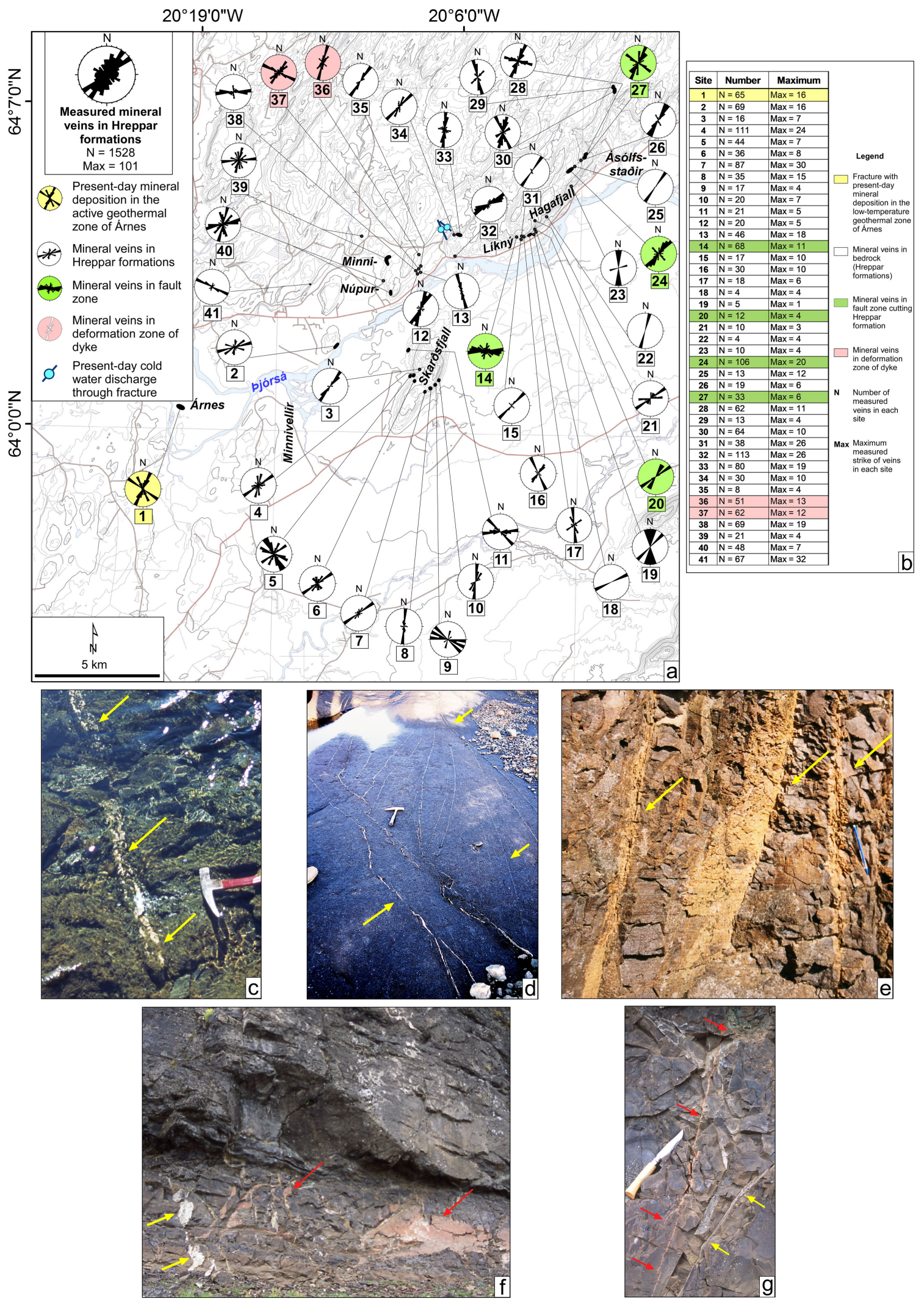

Figure 9. Mineral veins. (a) Locations of the measurement sites and rose diagrams of the strikes of the veins, coloured according to the relative age of their host rock and in the fault zones; (b) The table showing the details of the measurements; (c) to (g) Photographs of the veins, their thicknesses, geometry and infilling in the study area. 


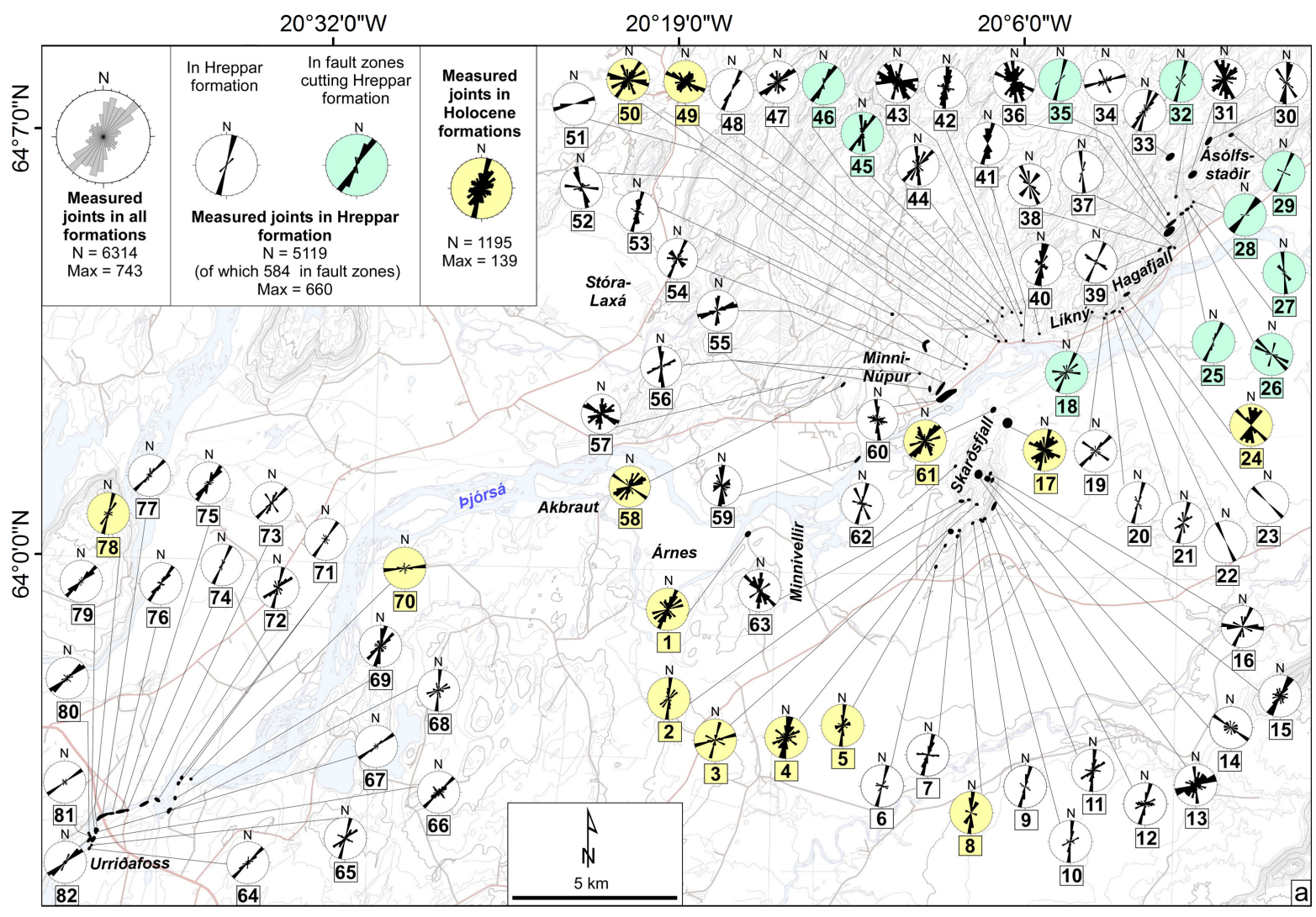

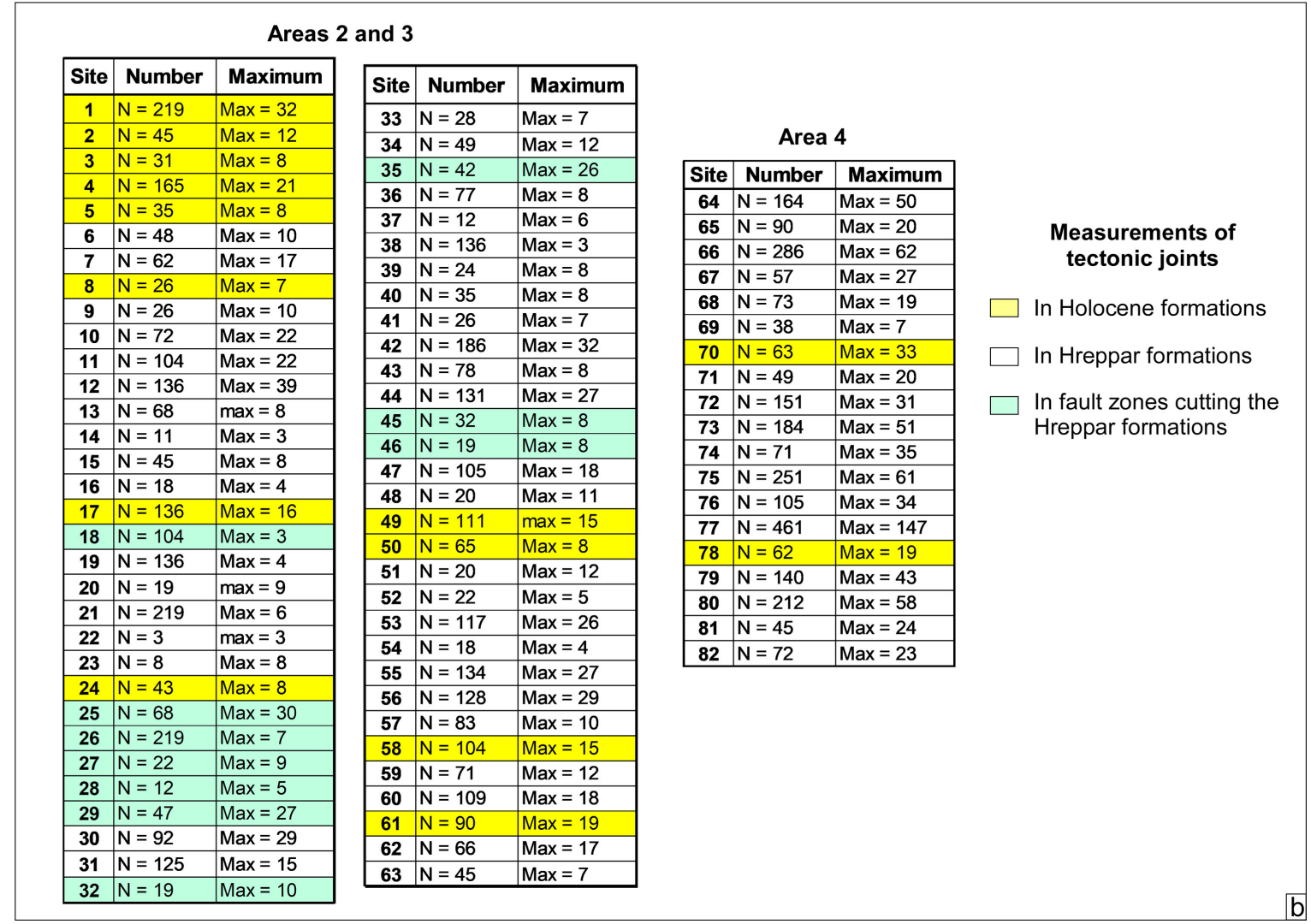

Figure 10. Tectonic joints. (a) Locations of the measurement sites and rose diagrams of the strikes of the joints, coloured according to the relative age of their host rock; (b) The table showing the details of the measurements. 

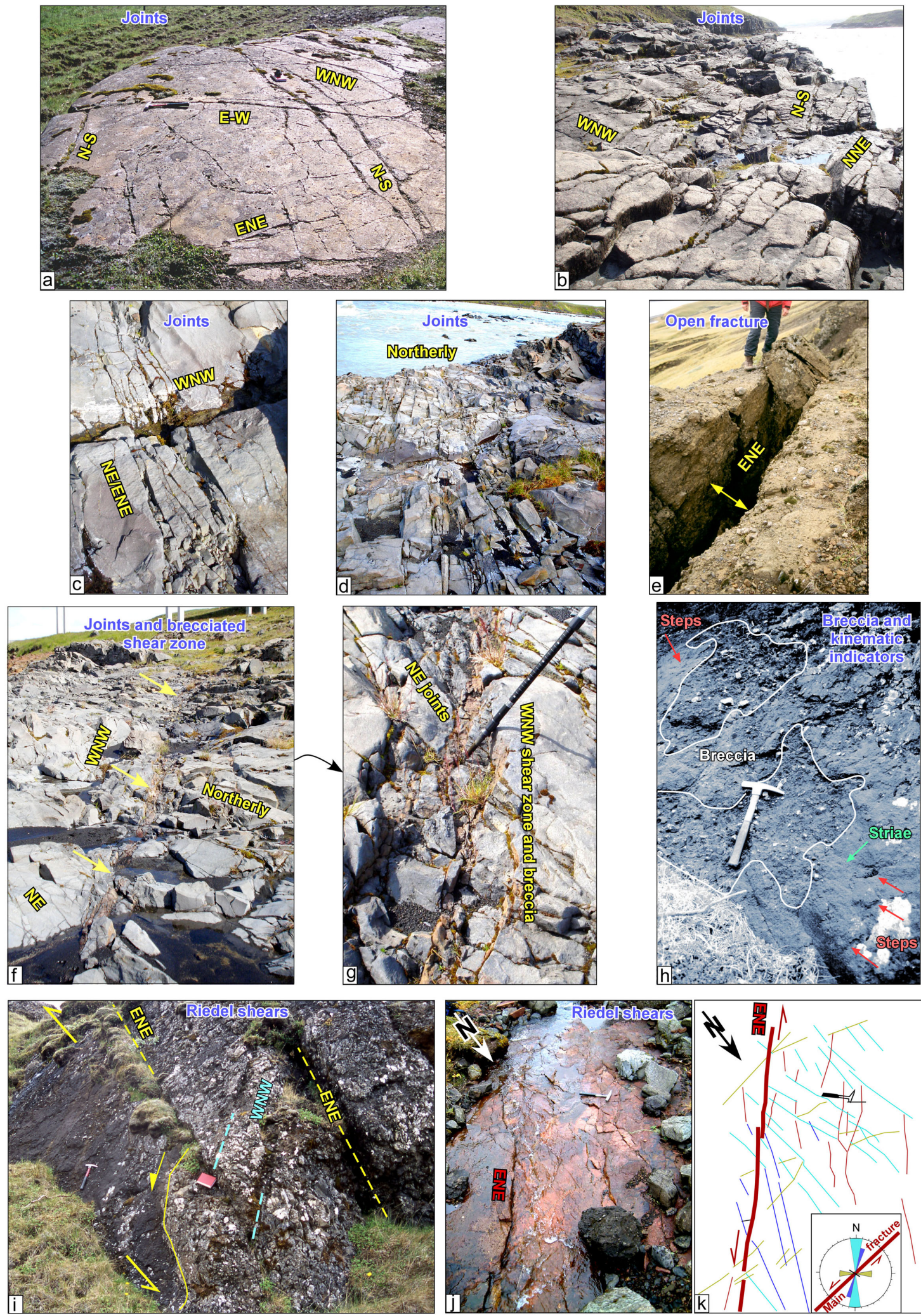

Figure 11. Tectonic joints, breccia and kinematic indicators in basaltic lavas and tuffs. (a) to (e) Joints of different sets with various density, spacing and opening; ( $\mathrm{f}$ ) and (g) A brecciated fault zone along a strike-slip fault cutting existing joints; (h) A brecciated and striated plane with steps indicating strike-slip; (i) Riedel shears caught between faults with normal- and strike-slip motions; (j) and (k) Sinistral fault and associated Riedel shears. 


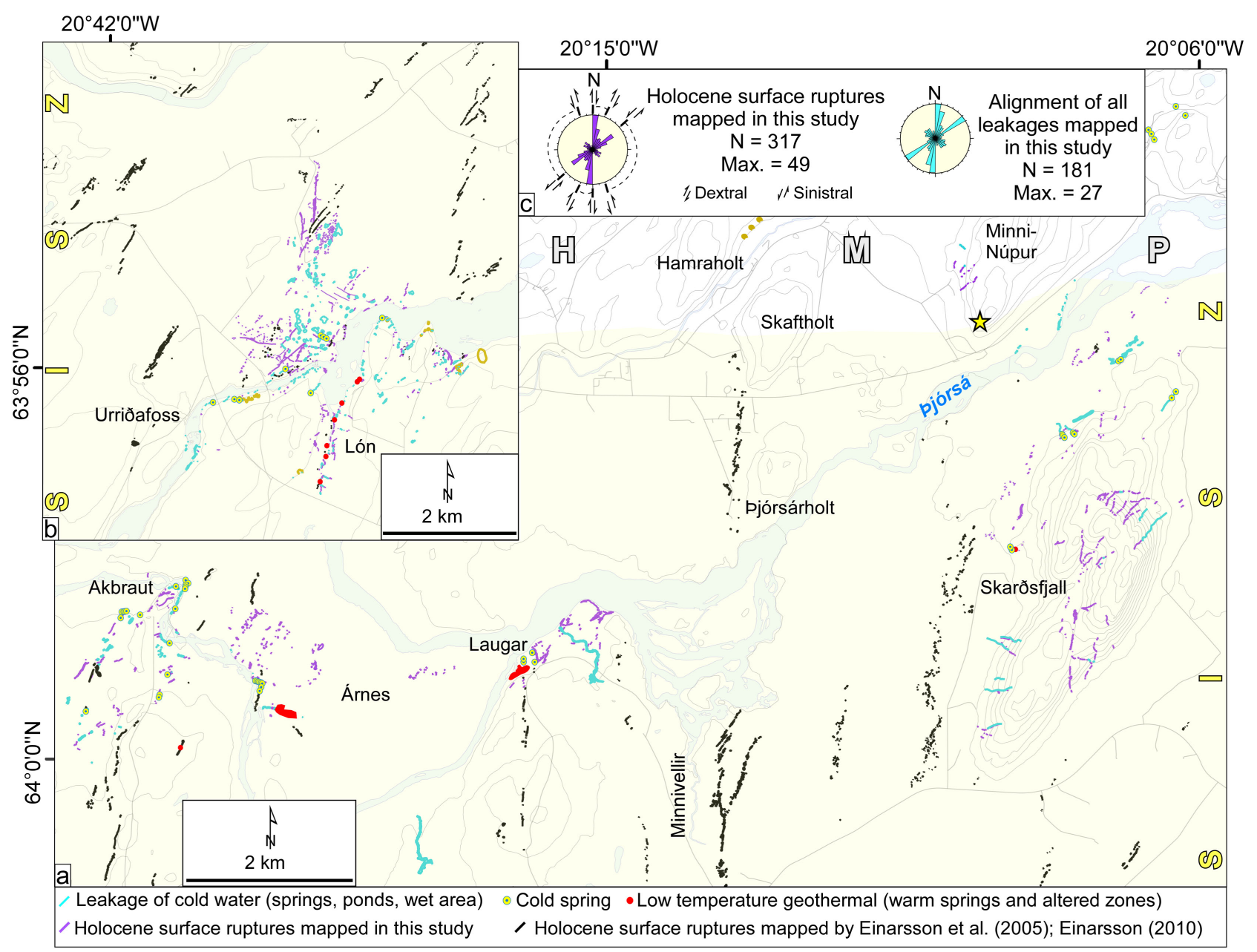

Figure 12. Holocene surface ruptures and leakages of cold and warm water mapped in the HMP and the SISZ. (a) and (b) The structures mapped in Areas 2 to 4. The black surface ruptures are from [140] and [141]; (c) Rose diagrams of the strike of surface ruptures and their motions, deduced from fracture geometry, as well as the alignments of the leakages.

the interglacial lavas $(\leq 0.7 \mathrm{Ma})$, and formations $<0.7 \mathrm{Ma}$. Before presenting the detailed geology, a regional overview of the series with respect to some major structural elements is necessary.

Area 1 has been primarily investigated for additional regional dips of the series and some cone-sheets (dip $20^{\circ}$ to $50^{\circ}$ ) around the SLCV. All measured dips in the four areas are compiled on (Figure 3(a) and Figure 3(b)). They indicate that under the interglacial lavas, the Hreppar formation dips from $2^{\circ}$ to $35^{\circ}$ (Figures 4(a)-(c)). However, the series can be divided into three groups based on their strikes and dip values. The series at Urriðafoss and to the southeast of the SLCV strike ENE/NE and dip towards the northwest. The dips are shallower at Urriðafoss $\left(3^{\circ}\right)$, and higher around Minni-Núpur $\left(7^{\circ}-10^{\circ}\right)$. The second series strike WNW with a dip to the northeast in areas to the northwest and east of Minni-Núpur as well as in Skarðsfjall. Their dip values are around $10^{\circ}$ in Skarðsfjall and to the northwest of Minni-Núpur, but between $2^{\circ}$ and $6^{\circ}$ from east of Minni-Núpur to the east of Hagafjall/Ásólfsstaðir where they flank the PCV. The highest dips $\left(20^{\circ}-30^{\circ}\right)$ are local and appear adjacent to the SLCV. 
The third series strike northerly and dip to the west. The dips are as high as $35^{\circ}$ at Miðfell in Flúðir (Figure 4(a)), and decrease to the north $\left(10^{\circ}-18^{\circ}\right)$ outside of the SLCV and to the east $\left(4^{\circ}-18^{\circ}\right)$ within the volcano (Figure $3(\mathrm{a})$ ).

An exact relation between the northerly, ENE and WNW striking series cannot be established as the mapped area lacks critical exposure in places, and the ages of the rocks are not always well known. Nevertheless, two major observations can be made (Figure $3(\mathrm{~b})$ ):

- Based on the successions of the series and the topography, the ENE striking series appears older than the series striking WNW. Furthermore, the series striking WNW cover the ENE striking formations unconformably in a gully to the east of Minni-Núpur. The WNW striking series are higher in altitude than the northerly striking formations filling the SLCV. They are thus likely younger. However, the relation between the northerly and the ENE striking series cannot be deduced from these data, nor the relation of the WNW striking series in Skarðsfjall and the ENE series on each side of the Pjórsá River.

- Previous interpretations of the axis of the Hreppar antiform and the extent of the SLCV [145] are also reported on Figure 3. If the axis of the antiform is $\mathrm{NE}$, with a bend to N-S near the SLCV, the series on each side of the antiform should strike NE and N-S with dips away from the axis. However, the mapped dips do not reflect such an axis as the WNW striking series dip to the northeast on both sides of the supposed axis, and the NE striking series towards northwest in the eastern flank of this antiform. The only anomaly in the area near the suggested NE axis of the antiform by [145] is the contact between the northerly and the WNW striking series. That contact is located at some 3 to $5 \mathrm{~km}$ to the west of the proposed axis, and is a structural unconformity, coinciding partly with the NNE course of the Stora-Laxá River in the same locality. Furthermore, the elongation of the Langholtsfjall hill above the flat land, as well as the dips of the series, point to a wider and more circular contour of the SLCV. The structural unconformity comes to a halt to the north of this volcano (Figure 3(b)).

\subsubsection{The Stratigraphy of Areas 2 to 4}

Areas 2 to 4 were subject of detailed stratigraphic and structural mapping. Area 2 is the largest and on a higher topographic level. It incorporates all stratigraphic units from Hreppar formation to the series $<0.7 \mathrm{Ma}$ (Figure 5). Areas 3 (Figure 6(a)) and 4 (Figure 6(b)) are in the low-land within the SISZ and are covered for the most by late glacial and Holocene Pjórsá lava although some units of the Hreppar formation crop out locally. The mapped series in the three areas are as follows:

- Hreppar formation has limited outcrops of ignimbrites and fine-grained lavas in the eastern part of the SLCV (Figure 5). Otherwise, the series consist of accumulated lavas and intercalated reworked sediments, primary hyaloclastites, tillites and fluvio-glacial sediments (Figures 4(d)-(i)), to the south of HMP 
and in Skarðsfjall within the SISZ. Tholeiite or olivine tholeiite lavas range from fine to coarse-grained, with or without vesicles, and are occasionally plagioclase-porphyritic. Individual flows can be columnar-jointed (Figure 4(d)), massif up to $10 \mathrm{~m}$ (Figure $4(\mathrm{e})$ ), or as thin as $0.5 \mathrm{~m}$. To the northeast of Ásólfsstaðir, the sheeted olivine tholeiite lavas of a shield volcano seem to be filling a N-S paleo-valley (Figure 4(f)), while in Urriðafoss, a scoria cone indicates a possible nearby eruptive site. The tillites and reworked sediments are fine to coarse-grained (Figure 4(i)), reaching up to tens of metres. Primary hyaloclastites are thick or thin layers, or mountains with fine-grained tuffs in the lower part and pillow lavas at their tops (Figure 4(g) and Figure $4(\mathrm{~h})$ ). The most geothermally altered area is the SLCV where intense intrusions and gabbro are present. However, zeolites are present throughout the series and reveal the level of erosion. While the regional alteration may be down to the stilbite zone, it is mostly within the chabazite/thomsonite zone, indicating an erosional level down to $500-700 \mathrm{~m}$ in Areas 1 and 2.

- The series < $0.7 \mathrm{Ma}$ consist of local valley infilling sediments (Figures $4(\mathrm{j})$-(n)), interglacial lavas (Figure 4(o)), and occasional fluvio-glacial sediments (Figure 4(p)). The $\leq 0.7 \mathrm{Ma}$ interglacial basaltic lavas cover the Hreppar formation in places, both in the HMP and within the SISZ (Figure 5 and Figure 6), with an erosional and perhaps a slightly structural contact. The lower parts of these lavas are columnar jointed and their upper part brecciated due to the presence of water at the time of their flow (Figure 4(o)). They reach a maximum thickness of $45 \mathrm{~m}$ locally to the east of Minni-Núpur. Sediments and tillites were found to the east of Hagafjall, filling a pre-existing erosional valley (Figures 4(j)-(n) and Figure 5). The lower part of these sediments displays fluvial erosion while the upper tillites are discordant on the Hreppar formation with a different dip direction (Figure 4(k)). The age of these valley infilling sediments is unknown, but considering their positions in the outcrop, they could either be the upper part of the Hreppar formation, or contemporaneous to the interglacial lavas.

- The Holocene formations consist of sediments and the Pjórsá lava. The sedimentary formations are eolian, fluvio-glacial, or silt and end-moraines (Figure 4(q)), 0.5 to $15 \mathrm{~m}$ thick. In places, the Holocene soil contains distinct Hekla tephra layers. The 8,600 yrs bjórsá lava covers vast surfaces in the lowland, particularly within the SISZ (Figure $4(\mathrm{r})$ ). The lava is of a porphyritic, aa-type with a rough surface (Figure $4(s)$ ), and columnar-jointed at the basis (Figure 4(t)). It reaches locally up to $20 \mathrm{~m}$ in outcrops.

Numerous basement faults, dykes, sills, and secondary fractures, as well as surface ruptures of earthquakes and seepages of water were also mapped along with the stratigraphy in the bedrock and Holocene formations of Areas 2 to 4 . They are detailed below.

\subsection{Major and Secondary Fractures in the Bedrock}

Note that on all rose diagrams, the letter $(\mathrm{N})$ indicates the total number of mea- 
surements, and (Max.) the most frequent strikes.

\subsubsection{Faults, Dykes and Striated Planes}

In Areas 2 to 4, basement faults are those cutting the Hreppar formation and the interglacial lavas. Dykes and a few cone-sheets are limited to the Hreppar formation under the interglacial lavas, while striae were found along few faults and dykes in the basement rocks of the Hreppar formation (Figures 7(a)-(c) and Figures 8(a)-(m)).

- About 262 short and long fault segments were mapped in outcrops (Figure $7(\mathrm{a})$ ). They fall within six sets, striking dominantly northerly $\left(\mathrm{N} 170^{\circ} \mathrm{E}\right.$ to $\mathrm{N} 20^{\circ} \mathrm{E}$ ), then NNE $\left(\mathrm{N} 20^{\circ}-\mathrm{N} 40^{\circ} \mathrm{E}\right)$, ENE (peak at N50 - N60 ${ }^{\circ} \mathrm{E}$ ), and E-W (peak at $\mathrm{N} 80^{\circ}-\mathrm{N} 90^{\circ} \mathrm{E}$ ). The least frequent sets and their peaks are WNW $\left(\mathrm{N} 110^{\circ}-\mathrm{N} 120^{\circ} \mathrm{E}\right)$, and $\mathrm{NW}\left(\mathrm{N} 140^{\circ}-\mathrm{N} 150^{\circ} \mathrm{E}\right)$. All six sets have dip-slip, as deduced from displacements of the stratigraphic formations (Figures $8(\mathrm{a})-(\mathrm{c})$ ). A few faults have a dip-slip (throw) of $<1 \mathrm{~m}$, but the throw of most faults is between 1 and $10 \mathrm{~m}$, and $1 / 3$ of the fault population has a throw $>10$ m. Except for a NNE rift-parallel fault to the east of Hamraholt that displaces the ignimbrites by $40 \mathrm{~m}$, the highest throws are along N-S faults, with $35 \mathrm{~m}$ at Líkný (Figure 8(a)), $25 \mathrm{~m}$ to the south of Skarðsfjall, and $\geq 18 \mathrm{~m}$ in Miðfell and in Pjórsárholt. Although poor outcrop conditions prevent accurate estimates, other N-S faults in Hagafjall and Ásólfsstaðir could have similar high throws in the HMP. Basement faults also display evidence of strike-slip motions as indicated by striae and breccia, but mostly by their typical geometry such as left- and right-stepping arrangements similar to the dextral and sinistral surface ruptures of earthquakes, or horsetail splays. In the absence of reliable horizontal marker horizons, the magnitude of shear motions could not be determined. Regardless of their type, the dip values of faults are between $70^{\circ}$ and $90^{\circ}$, indicating a steeply-dipping fault population. A fault plane of any strike can dip towards either direction, sometimes forming gentle horsts and grabens. However, most ENE and E-W faults in the HMP near the shore of the Pjórsá River dip towards the southeast and south.

- About 340 dykes and cone-sheets, and a number of sills were mapped. The smaller intrusions are not shown on maps due to their dimension (Figures 5-7), and the thickness of those shown is exaggerated. Dykes dip $50^{\circ}$ to almost $90^{\circ}$ (Figures $8(\mathrm{~d})$-(i)), sills $20^{\circ}-0^{\circ}$ (Figures 8(i)-(1)), and cone-sheets $50^{\circ}-20^{\circ}$ (Figure $8(\mathrm{~m})$ ). Sills could be fed from minor cone-sheets or dykes, or be conspicuous and fed by major dykes. All intrusions are columnar jointed, with black or brown chilled margins of 1 to a maximum of $10 \mathrm{~cm}$ thickness (Figure $8(\mathrm{k})$ ). Despite most intrusions are in the proximity of the SLCV and few even inside the volcano, hand specimens showed no acidic intrusion. They are all basaltic, similar to the tholeiite and olivine tholeiite lavas. Dykes can be dense and fine-grained, or coarse-grained and vesicular. Their geometries range from straight to undulating, with en échelon segmentations, bifurcating, and ending upwards or downwards. They shape 
equally the landscape and the waterfalls (Figure $8(\mathrm{~d})$ ). The dominant strike of the dykes is northerly, then NNE, ENE, and the least E-W. Similar to faults, NNE rift-parallel dykes are not dominant, and many N-S, ENE and WNW/NW dykes are injected into faults of the same directions. Dyke density is unusually high in Skarðsfjall where most of the WNW and NW dykes are concentrated (Figure $7(\mathrm{a})$ and Figure $7(\mathrm{~b})$ and Figure 8(f)). Sills are $<0.5 \mathrm{~m}$ to $15 \mathrm{~m}$ thick, while cone-sheets are single injections with up to $0.5 \mathrm{~m}$ thickness (Figure $8(\mathrm{~m})$ ). Generally, dykes are single injections with thicknesses of a few centimetres to $3 \mathrm{~m}$ (Figures 8(d)-(i)). The N-S and ENE dykes are the longest. However, the northerly dykes are the thickest as they reach up to $17 \mathrm{~m}$, with multiple injections, and evidence of being older eruptive fissures (Figure $8(\mathrm{~g})$ ). Dykes of Skarðsfjall are only in the lower part of the hyaloclastites. They are organised around a circle at the intersection of N-S, ENE and WNW faults (Figure 7(a)), have elongated vesicles parallel to their edges, and are likely the feeders of the hyaloclastites. The intrusions are fewer and thinner in the $500-700 \mathrm{~m}$ eroded Hreppar formation than in the 1500 m eroded crust of West Iceland [146], indicating that their density and size increase with crustal depth (Figure 8(n)).

- Major fault planes are generally eroded and the 110 striated planes were measured on secondary associated faults or on edges of dykes (Figure 7(a) and Figure $7(\mathrm{c}))$. These striae differ from striations and flow structures that occur on dyke edges due to cooling (Figure 8(o)). The 110 striated planes were collected on shiny planes, in presence of steps, Riedel shears or other kinematic indicators of faulting (Figure 8(p)), and occasionally covered with secondary minerals and iron oxidation. Similar to faults and dykes (Figure $7(\mathrm{a})$ ), the striated planes strike dominantly northerly, but also ENE, then NNE. The planes striking E-W, WNW and NW are the least frequent. The pitches of striae on the planes indicate a wide range of fault motions from $0^{\circ}$ (pure strike-slip) to $45^{\circ}$ (oblique-slip) and $90^{\circ}$ (dip-slip). Strike- and oblique-slip motions are as common as normal-slip, but reverse-slip is less frequent (Figure $7(\mathrm{c})$ ). The dataset shows several complexities as normal, dextral and sinistral motions are along the same fracture sets. Furthermore, on an individual plane, striae can turn from normal- to strike-slip, several generations may exist without cross-cuttings, normal-slip can cut the strike-slip and vice versa. The most incoherent fault motions were observed on an ENE plane detaching a block from the cliff above Minni-Núpur in the June 2000 earthquakes. That plane hosts six sets of striae with normal, dextral and sinistral slips without a single cross-cutting. In spite of the complexities, the sinistral motion represents the highest number of measurements and appears on northerly, NE/ENE, E-W and NW planes, while dextral motion appears more along the northerly set. The few reverse-slip striae are on northerly planes and mostly associated with dykes (Figure 7(c) and Figure 8(q)). The significance of the fault-slip data is discussed in Chapter 5.1. 


\subsubsection{Mineral Veins, Joints and Breccia}

Measured secondary fractures are discussed separately below.

- About 1528 mineral veins were measured mostly in the lower and middle parts of the Hreppar formation, with a few directly in faults zones and along dykes (Figure 9(a) and Figure 9(b)). The veins are longer (several metres) and thicker (up to $\sim 10 \mathrm{~cm}$ ) near the SLCV (Figure 9(c)) and the PCV (Figure 9(d)), and are filled with zeolites. They cut the lavas, reworked sediments and tuffs, and are generally short (up to a metre) and thin $(<2 \mathrm{~cm})$. Hand specimens indicate that their infilling is zeolites such as thomsonite and chabazite (Figure 9(c)), clay, iron oxide, and even calcite and opal (Figures 9(e)-(g)). The strike of the veins varies from outcrop to outcrop, reflecting the adjacent and often eroded major faults or dykes to which they are associated. However, their cumulative strikes (Figure 9(a)) show the same sets as in other fracture types but with a different frequency. Unlike faults, dykes and striated planes, the mineral veins are dominantly ENE and NNE, then northerly and WNW. No clear relation appears between the strikes of the veins and their infilling, but the thickest veins are in the ignimbrites of Hamraholt and in the Hreppar formation between Minni-Núpur and Hagafjall, and they strike respectively, WNW and ENE.

- Some 6314 tectonic joints and secondary fractures were measured in Areas 2 to 4 (Figure 10(a) and Figure 10(b)). Of these, 5119 joints are in lavas, sediments, and hyaloclastites of the Hreppar formation, as well as in fault zones cutting those series, while 1195 of the joints are in Holocene formations. The 5119 measured joints at individual sites in the Hreppar formation reflect the strikes of faults and dykes to which they are associated. Their combined strikes in the Hreppar formation are dominantly northerly and NNE/NE in the fault zones cutting those formations, but northerly in Holocene formations. However, the cumulative strikes of joints in all formations show that contrary to faults, dykes, and striated planes, tectonic joints strike dominantly ENE, then northerly, and finally NNE and WNW. These dominant regional strikes are, therefore, more comparable to mineral veins (Figure 9(a) and Figure 10). The joints have a variety of geometry and spacing. They can be regularly spaced along intersecting sets (Figure 11(a) and Figure 11(b)). Along single sets, they can be tightly parallel and separated by unbroken rocks (Figure 11(c)), or densely populated adjacent major fractures (Figure 11(d)). Regardless of strikes, joints display extension and opening, generally a few millimetres to centimetres in the basement rocks (Figures 11(a)-(d)), but exceptionally up to $0.7 \mathrm{~m}$, particularly in cliffs above the slopes when a part of the opening could be gravitational (Figure 11(e)).

- Fault breccia was found in a few fault zones, along the fault trace, or on fault planes themselves (Figures 11(f)-(h)). Joints in fault breccia are generally parallel in case of pure normal faults, but complex in case of strike- and oblique-slip faults, or when fractures of various sets intersect. Riedel shears are the main secondary fractures resulting from strike-slip motions. Their inte- 
ractions with the main faults can cut the blocks into wedges (Figure 11(i)), otherwise they appear as various sets of secondary fractures associated with the main strike-slip structure (Figure 11(j) and Figure 11(k)). Regardless of sets, the width of the fault breccia ranges between 0.5 and $5 \mathrm{~m}$, with the highest thickness associated with strike- and oblique-slip faults of the basement, particularly if the faults have been reactivated. The matrix of breccia along major faults could be clay, oxidised rock, with or without the presence of zeolites, silica and calcite. But in case of minor structures, the breccia is rather homogeneous, lacking matrix.

\subsection{Holocene Structures and Leakages}

In addition to the 1195 joints in the Holocene formations (Figure 10(a)), about 317 segments of Holocene surface ruptures, and 181 points of leakages (cold and warm water) were mapped in Areas 2 to 4 (Figures 12(a)-(c)). The surface ruptures and leakages are primarily in the low land of the SISZ although some were also found at higher altitude such as in Skarðsfjall or in Minni-Núpur.

- The surface ruptures are typical sink-holes and linear short segments (Figures 13(a)-(f)), or short open fractures sometimes filled with Holocene sediments (Figures 13(g)-(j)). They cut the soil, moss, scree, aeolian sediments, semi consolidated sand, the Pjórsá lava, and the Hreppar formation. Sink-holes are circular, oval or elongated, and their collapsed geometry is conical at depth. Despite earthquakes with $\mathrm{M}_{\mathrm{L}} 6$ - 7 in the SISZ, push-ups are rare in the study area. Generally, it is difficult to identify the surface ruptures in the Pjórsá lava due to subtle similarities with lava structures. Combined analysis of aerial photographs and outcrop mapping indicates that the mapped surface ruptures, particularly in Area 4 (Urriðafoss), are of tectonic origin and not lava tubes, degassing craters, river channels, or related to the Pjórsá lava front. Other Holocene structures are minor (horseshoe) landslides aligned above/near deeper source faults of earthquakes (Figure $13(\mathrm{k})$ ), or major landslides occurring after earthquakes such as in 2000 (Figure 13(1)). Surface ruptures display evidence of extension and strike-slip, and are surface expressions of deeper shear faults. They are organised in individual segments of a few to hundreds of metres long, separated by gaps. Segments can extend over $20 \mathrm{~km}$, indicating the maximum length of the underlying source faults. Extension appears as local openings of a few centimetres to $0.5 \mathrm{~m}$ and rarely up to $4 \mathrm{~m}$, while normal-slips reach a maximum of $0.5-1 \mathrm{~m}$. In the lack of marker horizons, the shear motions are deduced from the en échelon geometry of the segments, where a left-stepping array indicates dextral motion, and a right-stepping array sinistral motion (Figure 12). The main conjugate source faults are the N-S dextral and ENE sinistral strike- and oblique-slip faults, although surface ruptures also align on WNW, $\mathrm{NW}$, and to a lesser degree on short E-W segments, all with sinistral motion in general. Surface ruptures also appear along NNE rift-parallel segments, without being frequent and having coherent en échelon arrangements. The 


\section{Surface ruptures of earthquakes}
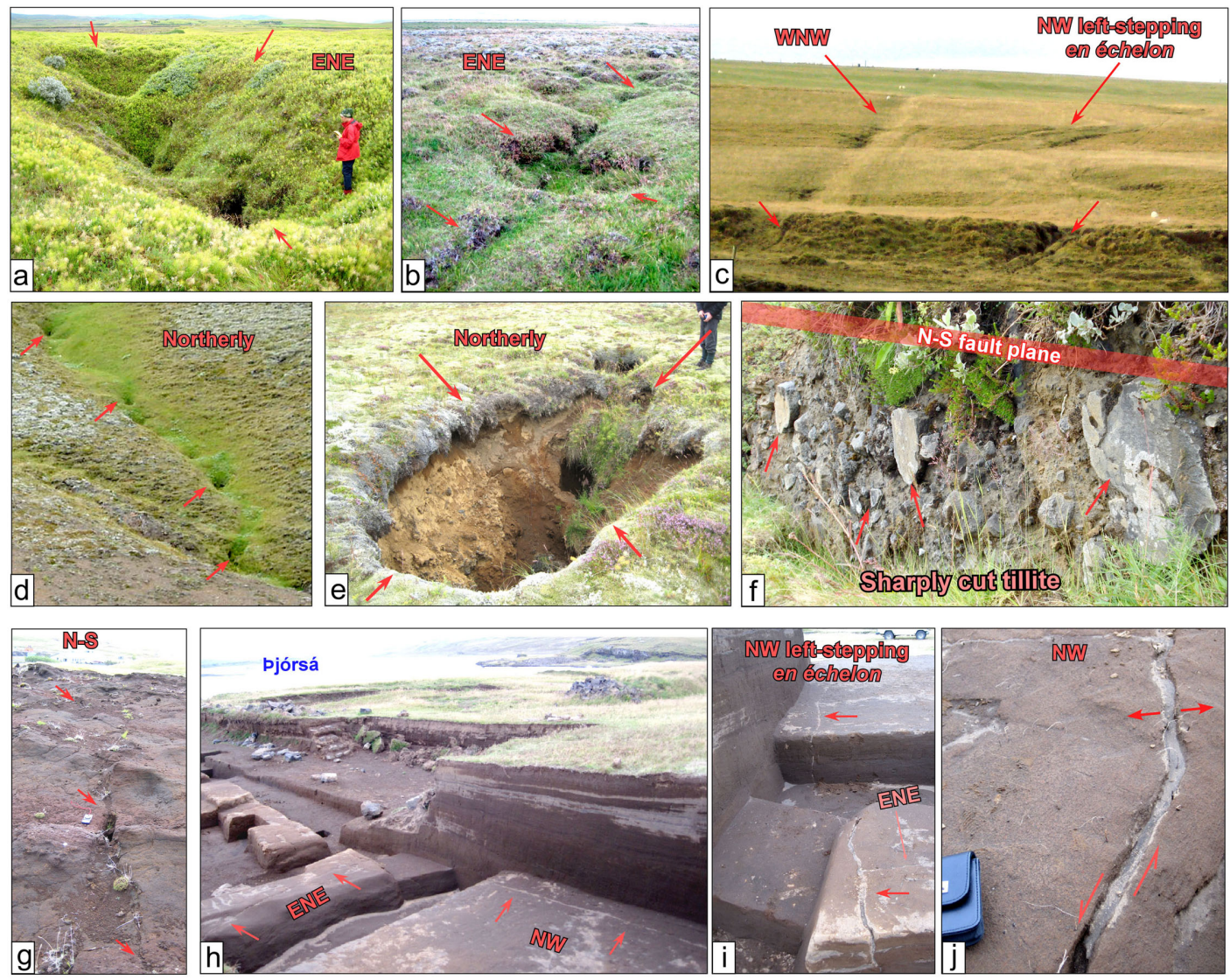

Horseshoe structures and small landslides

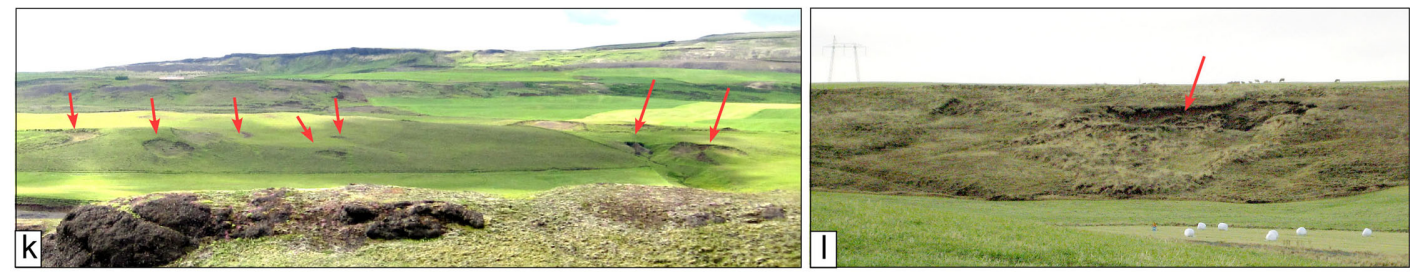

Leakages of cold and warm geothermal water
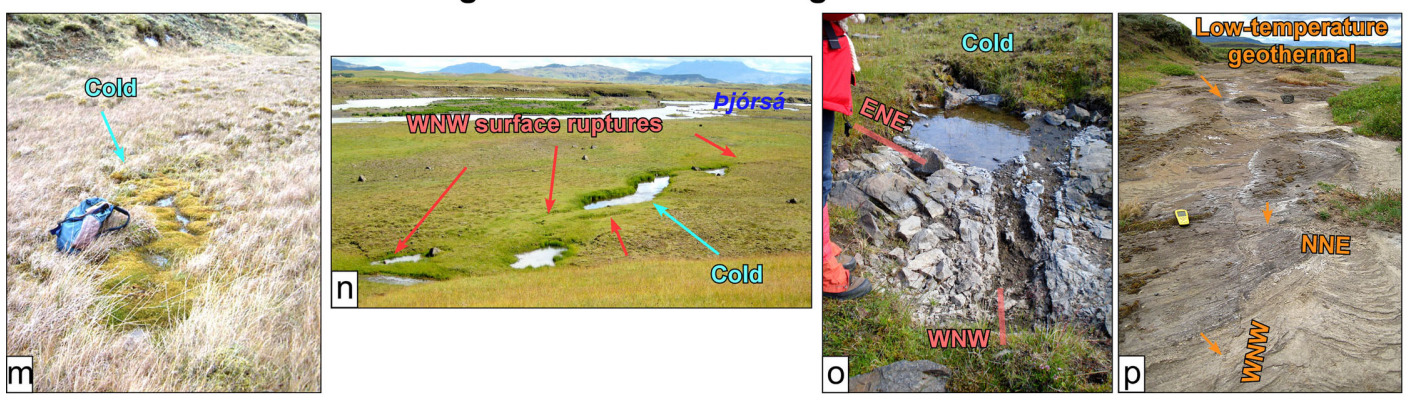

Figure 13. Surface ruptures and leakages. (a) to (e) En échelon surface ruptures of various sizes and geometry; (f) Elements of a tillite cut sharply by a N-S dextral strike-slip fault; (g) An open fracture in aeolian sediments; (h) to (j) Holocene soil with Hekla ashes in an archaeological site, cut by fractures and filled with Holocene sediments. Note the left-stepping arrangement, extension and shear motion; (k) The northerly alignment of small landslides (horseshoe); (l) A landslide near the epicentre of 2000 earthquakes; $(\mathrm{m})$ to $(\mathrm{p})$ Leakages of cold water on or at the intersection of basement fractures and surface ruptures, and the overall WNW elongation of low-temperature geothermal activity in Árnes. 


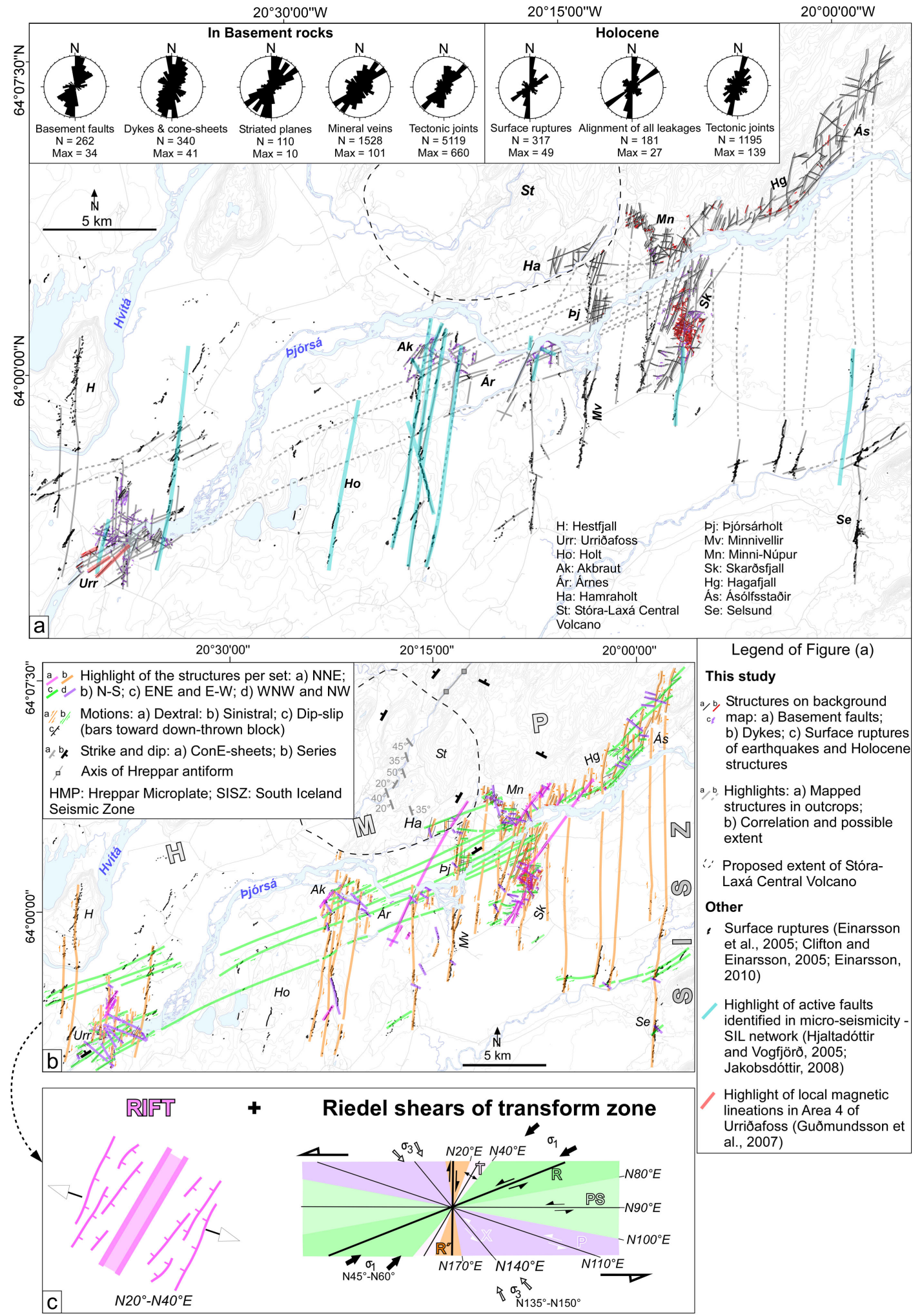

Figure 14. Interpretation of the structural pattern. (a) All basement faults and dykes, surface ruptures, and rose diagrams of fractures in the SISZ and the HMP mapped in this study. As a complement, source faults of historic and 2000 earthquakes in the SISZ, the active faults deduced from microseismicity, and the local magnetic structures from the literature are also compiled. All datasets are interpreted here; (b) The fracture pattern coloured per set; (c) Schematic models showing that the observed structural pattern is a combination of rift-parallel extensional fractures and the Riedel shears of the transform zone. 

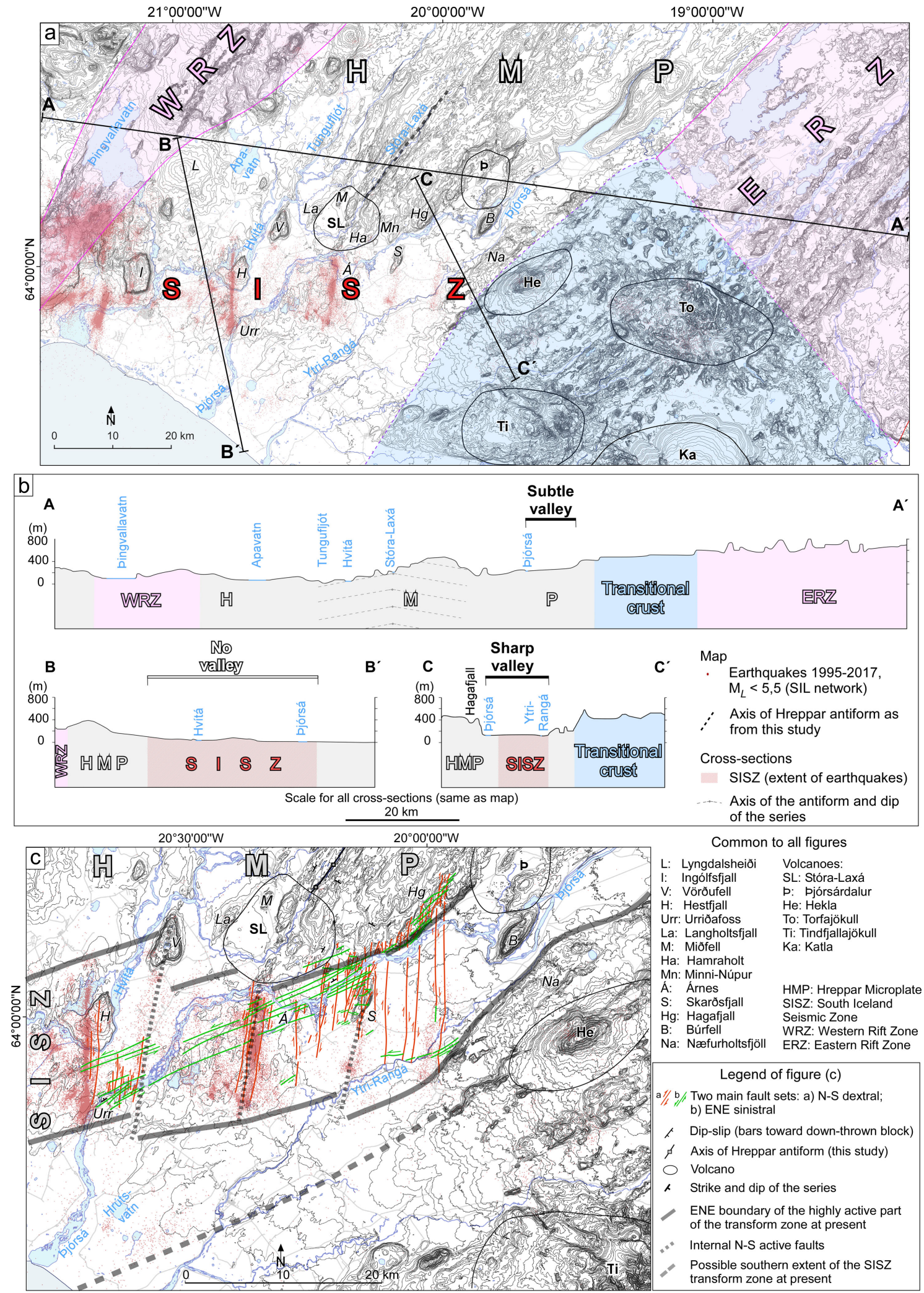

Figure 15. Interpretation of the boundary of the SISZ. (a) and (b) The location map and cross-sections through the WRZ, the ERZ, the HMP and the SISZ showing the topography of the structural domains and the configuration of a narrow ENE valley on the trace of the SISZ; (c) Interpretation of the ENE boundary of the SISZ based on ENE and N-S fracture sets, and the extent of earthquakes. 


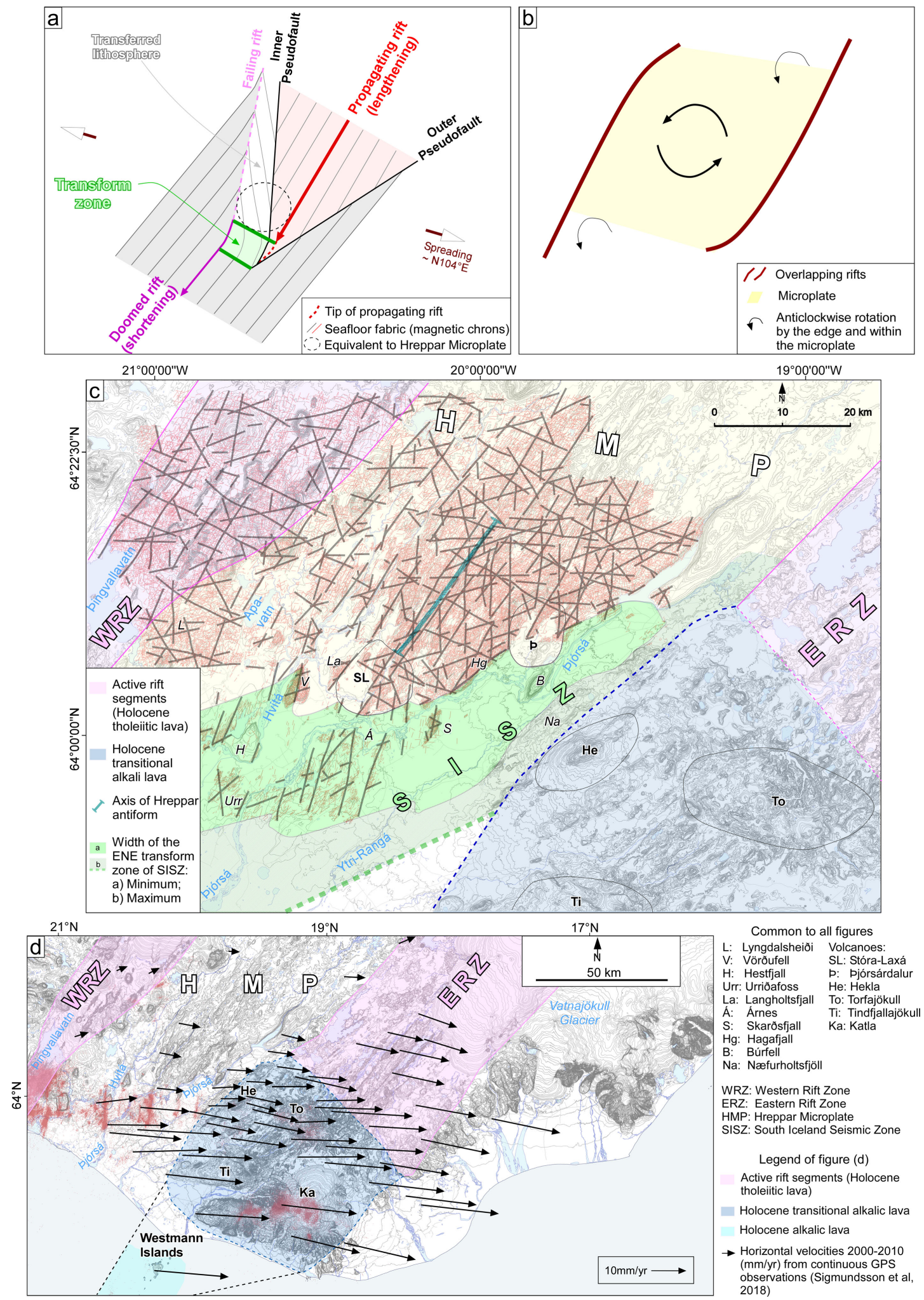

Figure 16. Interpretation of the observed structures with respect to regional tectonic elements. (a) and (b) respectively, models of a propagating/receding rifts (modified from [157]), and the rotation of a microplate between two overlapping rifts (modified from [67]); (c) Selected individual fracture segments on aerial images are highlighted to check for their continuity. They do not show a rotation in their strikes within the microplate; (d) Horizonal velocities due to plate spreading obtained by continuous GPS measurements (modified from [120]) also show no rotation in the short term in the HMP. 


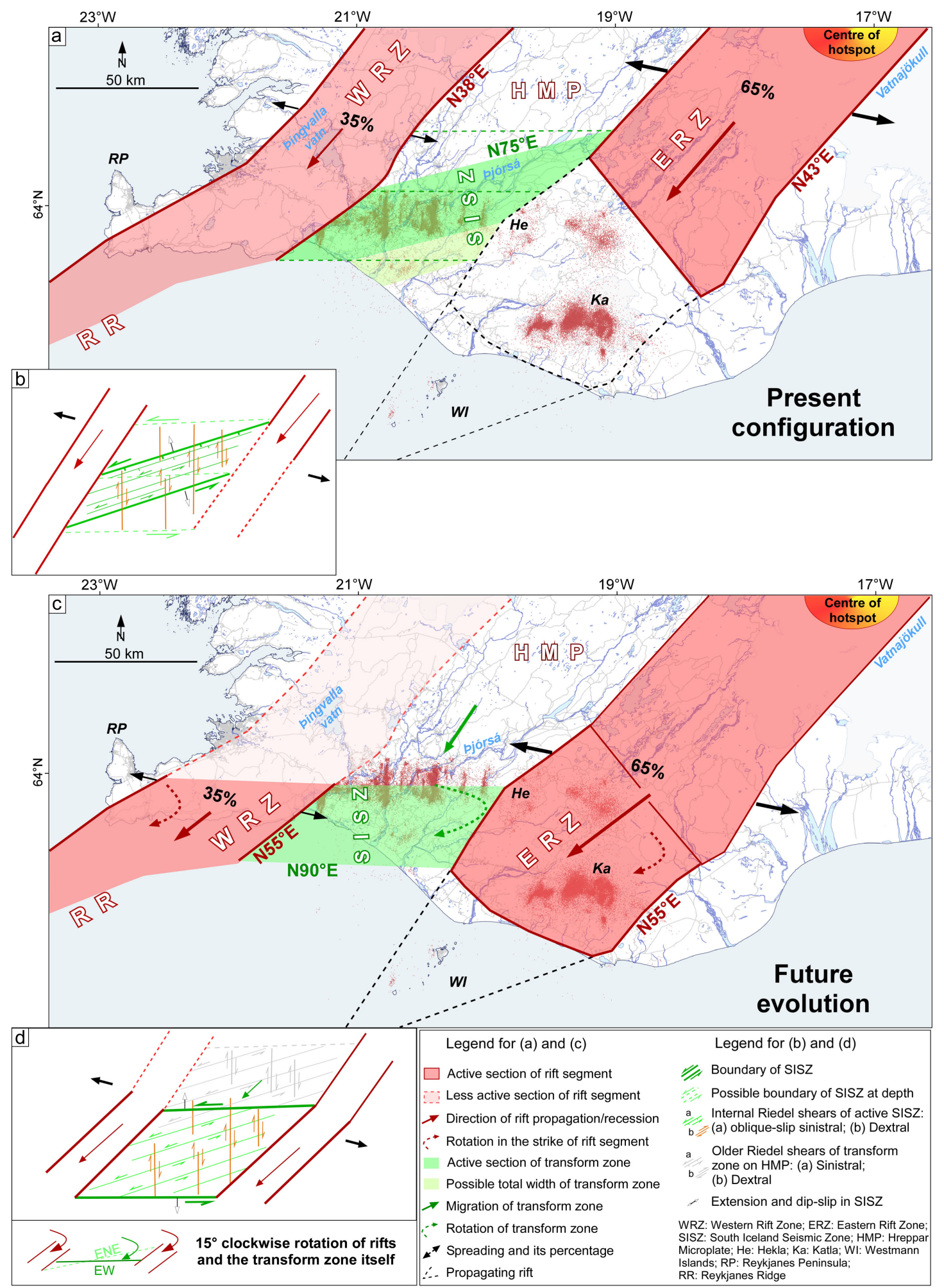

Figure 17. Interpretation of the observed fracture pattern in terms of unstable plate boundaries. (a) The present configuration of the SISZ as an ENE transform zone highly oblique to the propagating ERZ and the receding WRZ; (b) The boundaries and the main active fracture sets accommodating the sinistral motion of the SISZ; (c) The future evolution where the ERZ and the WRZ propagate and recede along their sections striking $\mathrm{N} 55^{\circ} \mathrm{E}$. As a consequence, the migrating transform zone also rotates from ENE to E-W; (d) Future boundaries and main active fracture sets of the SISZ. Note that at all stages, the migrating transform zone leaves behind older Riedel shears in the microplate. 
five sets with strike-slip motions form a Riedel shear pattern. All these fracture sets also appear in the present-day seismicity of the SISZ [135] [137]. The mapped structures in the study area are identical to those of the 2008 earthquake doublets in Hengill [117], and to the 2000 and historic earthquakes mapped in this part of the SISZ by [140] [141]. For comparison and complement, the faults mapped by [141] are also reported on Figure 12(a) and Figure 12(b), as they are in continuation of those mapped in this study.

- A number of cold springs, small ponds, wet areas, and local low temperature geothermal areas and warm springs were mapped (Figure 12(a) and Figure 12(b)). Wet areas covered by green moss contrasting the grass have the lowest discharge (Figure 13(m)). The springs burst through Holocene sediments or soil, have low to moderate discharges and are accompanied by swamp and algae. Ponds are often seepages through underlying young fractures (Figure 13(n)), or are sometimes sink-holes filled with water. In basement rocks, seepages are either through single fracture on or near fault zones, with very low discharges, white deposition and green moss. Or they are at fault intersections, especially when one fault is a strike-slip (Figure 13(o)). Low-temperature geothermal activity was found only in the three localities of Laugar, Lón, and the island of Árnes, with very low discharges, associated or not with cold leakages (Figure 12(a) and Figure 12(b)). The springs of Laugar are $16.4^{\circ} \mathrm{C}$ to $47.2^{\circ} \mathrm{C}$, in an area where drilled wells yielded up to $63.5^{\circ} \mathrm{C}$ hot water. In Lón, the warm springs are $10.1^{\circ} \mathrm{C}$ and $24.5^{\circ} \mathrm{C}$, and they appear between the aligned rows of cold-water leakages. Due to a low water level at the time of mapping, active warm springs were not found in Árnes. However, a large zone of geothermal alteration with present-day mineralisation was mapped (Figure $13(\mathrm{p})$ ), near a borehole yielding $50^{\circ} \mathrm{C}$ hot water. The three local low temperature manifestations are aligned ENE in Laugar, WNW and NW in Árnes, and northerly in Lón.

- The main structural feature of the Holocene joints, surface ruptures and the leakages is their identical trends. As their respective rose diagrams show, they strike dominantly northerly then ENE, and secondarily NNE, ENE, E-W and WNW (Figure 10 and Figure 12(c)). The similarity in the strikes of the three structural features reflects the latest status of tectonic deformation. It indicates that the joints likely result from the activity of the source faults of earthquakes during Holocene, and that all the dominant and secondary shear fractures are permeable host fractures channelling cold and warm water (Figure 12(c)).

\section{Interpretation}

A total of 8942 faults, dykes, mineral veins, tectonic joints, surface ruptures, leakages of cold and warm water, and 110 striated planes were studied in the outcrops of Areas 2 to 4 (Figure 14(a)). They cut the 500 - 700 m eroded Hreppar formation, the interglacial lavas, the Holocene and superficial formations of the HMP and the SISZ. Due to their high number, these observations represent the 
tectonics of the upper oceanic crust, with insights from the scale of individual fractures to that of diverging plate boundaries. For interpretation, all major structures are compiled onto a single map and their traces highlighted regionally (Figure 14(a)). To provide a deeper understanding, the historic surface ruptures mapped by [140] [141], some active faults deduced from micro-earthquakes [113] [147], and a few local magnetic structures [148] are also reported on Figure 14(a) and Figure 14(b). To reiterate, "older" refers to structures with higher dip-slips and sharper traces, indicative of a longer life-span, and "younger" to fractures cutting the Holocene formations such as surface ruptures, and structures with finer traces and less or no dip-slips.

\subsection{The Structural Pattern}

While the NNE fractures appear dominant on the tectonic lineament map where almost half of those regional structures is within the WRZ reflect rifting (Figure 2 ), the rose diagrams of fracture types from outcrops show the presence of six sets in the SISZ and the HMP. Basement faults, dykes, joints in Holocene formations, surface ruptures and leakages strike dominantly northerly, then ENE, and to a lesser degree NNE, E-W, WNW and NW (Figure 14(b)). However, mineral veins and tectonic joints, which are generally associated with basement faults and dykes, strike dominantly ENE.

The dextral and sinistral motions of the mapped older and younger N-S and ENE structures, identified from their en échelon geometry and striae, are identical to those of the source faults of historic [141] and the 2000 earthquakes [149], as well as to the focal mechanisms in the SISZ (e.g. [116] [137]). However, the present study identifies shorter E-W, WNW, and NW shear fractures as additional sets, all of which have sinistral motion. Although micro-earthquakes align primarily on the active N-S faults in the study area, some do also align on WNW/NW structures, supporting the existence of these shear fractures (Figure 14). The five sets with strike-slip motions form a Riedel shear pattern where the main N-S dextral and ENE sinistral structures act as (R') and (R), respectively, the short NNE subtle structures are tension fractures or $(\mathrm{T})$, and the E-W to NW structures would be PS, P and X (Figure 14(c)). Such a pattern is typical of a shear zone, which in this case is the SISZ transform zone. However, the overall mapped structural pattern is a combination of the Riedel shears and the NNE rift-parallel extensional fractures where the shear fractures dominate in the SISZ and this part of the HMP (Figure 14(b) and Figure 14(c)).

The observed strikes and motions fit with a maximum principal stress $\mathrm{N} 45^{\circ} \mathrm{E}$ to $\mathrm{N} 60^{\circ} \mathrm{E}$ [138], in agreement with a $\mathrm{S}_{H \max }$ ranging between $\mathrm{N} 29^{\circ} \mathrm{E}$ and $\mathrm{N} 62^{\circ} \mathrm{E}$ in South Iceland as deduced from borehole, earthquake and geological data [150].

The attempt to interpret all striated planes of the present study, including the opposite motions in the basement rocks, the complex cross-cuttings, and the rare reverse-slip slickensides (Figure 7 (c), required up to eight sets of stress fields and too many fluctuations. Some of the measurement sites here are the 
same as in the study of [151], who interpreted the complex fault-slips with several stress fields and compression parallel and perpendicular to rift axis. The present study proposes kinematic alternatives for the complex motions, which are mostly located on planes between Minni-Núpur and the SLCV (Figure 7(a)). Some of the opposite strike-slip motions along the same sets may be due to block adjustments related to the collapse of the volcanic caldera. The normal- and strike-slip striae cutting each other alternatively could indicate simultaneous motions. Finally, the few reverse-slip striae mainly on dykes' edges could result from friction between fracture planes during repeated magma injections.

\subsection{Fracture Reactivation, Cumulative Slips, and Intrusions into Strike-Slips}

Fracture reactivation can be interpreted from the connectivity of young and older fractures, cumulative dip-slips, ruptures of older structures during historic and present-day earthquakes, and magma injections into pre-existing faults.

Fracture segments of the six sets stretch from the SISZ into the HMP where they align with older basement faults but also dykes. Single active N-S faults are up to $10 \mathrm{~km}$ long in the SISZ where they show dextral motion. But with an extension into the HMP and dextral oblique-slip motion there, their length reaches $25 \mathrm{~km}$, such as the Selsund-Ásólfsstaðir Fault (Figure 14(a)). Similarly, individual young ENE segments are up to $5 \mathrm{~km}$ long in the SISZ, but they can be correlated over a $10 \mathrm{~km}$ distance within the transform zone, such as the segments to the north of Urriðafoss. The NNE rift-parallel segments are fewer, and the two longest normal faults stretch from the HMP into the SISZ (Figure 14(b)). The least frequent $\mathrm{E}-\mathrm{W}, \mathrm{WNW}$ and NW structures are, however, isolated segments either in the HMP or the SISZ. The fracture continuity from one structural domain to another clearly shows that faults of the SISZ are reactivation of older structures. In addition to the lengthwise connectivity, fracture reactivation is also expressed as ruptures of individual dykes and faults in many places along lengths, such as in Skarðsfjall and other basement rocks (Figure 5 and Figure 6 and Figure 14).

Fault slips are also indicative of fracture reactivation. In lack of horizontal marker horizons, the magnitude of offsets along strike-slips could not be determined, but as an indication, the offset of the N-S source faults in the SISZ is $2 \mathrm{~m}$ during single earthquakes [116], and their dip-slips up to $1.5 \mathrm{~m}$ [117]. The NNE normal faults have the highest dip-slip in the HMP ( $\geq 40 \mathrm{~m}$ in Hamraholt), but the set appears as open fractures with no or $<0.5$ dip-slip in the SISZ ("T" fractures). With up to $35 \mathrm{~m}$ throw, the N-S faults have the second highest dip-slip both in the HMP and in Skarðsfjall within the SISZ. Although with less throw, the ENE, E-W, WNW and NW fractures also display higher values of dip-slips ( $5 \mathrm{~m}$ to $\geq 15 \mathrm{~m}$ ) in the HMP than in the SISZ.

Many dykes are injected into existing faults, particularly in Area 2, where intrusions are on the traces of dominantly N-S, but also NNE, ENE and WNW 
faults (Figure 14(a)). Some dykes even present multiple injections and indicate re-opening and reactivation of the same host fractures during magma injections. Although NNE rift-parallel intrusions are favoured as the magmatic heat source of geothermal activity, the present study shows that dykes are frequently injected into dextral and sinistral shear faults of the transform zone. Magma injections into strike-slip faults perpendicular or oblique to rifts are not restricted to this area as examples are reported from the older structures of West Iceland [103], within the active TFZ of North Iceland [144] [152], in the young oblique rift of Reykjanes [143], and even during the 2014 Bárðarbunga fissure eruption north of Vatnajökull [153].

While the damage zones of historic earthquakes in South Iceland show reactivation of the same source faults over a period of 100 years [134] [154], the present study demonstrates that fracture reactivation is an ongoing process over longer geological time scales.

\subsection{A Major ENE Structural Zone}

In addition to local tectonic and magmatic behaviour of fractures in the oceanic crust, the present study also provides insights into regional deformation.

One prominent aspect is the relevant features of the ENE fractures. As mentioned above, ENE surface ruptures group into short individual segments, but the segments correlate well together over distances, indicating much longer ENE structures within the SISZ. Young ENE sinistral segments of surface ruptures that fall in the continuation of older ENE faults (and dykes) of the HMP are tightly parallel on both sides of the bjórsá River, forming an ENE structural weak zone with at least $5 \mathrm{~km}$ width. A few ENE segments are outside this zone, farther to the south (Figure 14(b)). This major ENE structural zone is at least 45 $\mathrm{km}$ long, i.e., the extent of the land studied here, but it could be longer. Within this zone, the great majority of the older ENE strike- and oblique-slip sinistral faults dip to the southeast, similar to shorter E-W, WNW and NW faults (Figure 14(b)). The Pjórsá River flows within this structural zone, and in many places its course is controlled by the individual young and older ENE mapped fractures. The fact that the prominent strike of mineral veins, tectonic joints and striated planes associated with basement fractures is ENE does reflect the strong presence of this set. Local surveys have also confirmed the presence of ENE magnetic anomalies coinciding with mapped ENE faults and dykes of Area 4 at Urriðafoss [148].

The ENE surface ruptures have been considered to be a secondary set, conjugate to the main N-S dextral source faults of earthquakes. However, the existence of this major ENE structural zone with most of the older ENE faults dipping to the southeast is symptomatic of a more severe deformation within the SISZ. The ENE fractures can indeed be deeper, rupturing locally during earthquakes, but they play an equal role to the N-S faults in accommodating the overall sinistral motion of the SISZ. This major ENE structural zone is further discussed in the following chapter as it has more regional implications. 


\section{Discussion}

As the observed structures reflect the deformation related to rifting, transform faulting and a microplate, their significance needs to be addressed in relation to these types of regional structures. Of the many tectonic aspects, we only interpret three features, briefly, within the space of this paper. These are the geometry and boundary of the SISZ transform zone, the rotation of the HMP, and the evolution of rift and transform segments in time. Known models are used as a basis for discussions despite being mostly from fast spreading centres.

\subsection{The Boundary and Trend of the SISZ}

Although a WNW trend has been suggested for the SISZ [88] [100] [132], its $\mathrm{E}-\mathrm{W}$ trend is mostly proposed based on the extent of the active and historic N-S faults [83], and the results of continuous GPS measurements [131]. As oceanic transform zones of slow spreading centres are characterised by narrow knife-cut valleys of $\sim 10$ to $30 \mathrm{~km}$ width [9] [24], and controlled by parallel boundary faults and internal faults oblique to the shear zone [9] [37], three cross-sections are made into the study area to check for a similar valley (Figure 15(a) and Figure 15(b)). The cross-section A-A' shows that the HMP rises in altitude gradually from the WRZ towards the ERZ, and that a subtle valley exists in the eastward continuation of the SISZ where the Pjórsá River flows (Figure 15(b)). The cross-sections B-B' and C-C' cut the SISZ obliquely. Although a sharp narrow valley on section $C_{-}-C^{\prime}$ coincides with the easternmost earthquakes of the SISZ, no valley appears along section B-B' to the west where the earthquakes of the transform zone are denser (Figure 15(b)).

An alternative is proposed here for the geometry and strike of the SISZ based on the ENE sinistral structural weak zone (Figure 14(b)), the extent of the N-S faults and the earthquakes, as well as the morphostructural elements (Figure 15(c)). The narrow ENE valley between east of Búrfell and Árnes on sections A-A' and C-C' is partly carved by a glacier and filled with Holocene bjórsá lava (Figure 5 and Figure 6). However, the origin of this valley is likely tectonic and its northern boundary controlled by the ENE sinistral oblique-slip faults dipping mostly to the southeast that are identified in this study (Figure 15(c)). The dense earthquakes between Árnes and west of Hestfjall appear on the map in the westward continuation of the same ENE valley. However, a relatively flat topography to the west may indicate a deeper ENE transform zone there, where a valley could be present at depth and fully covered by superficial formations (Figure 1(b)). The ENE boundary of the SISZ is likely irregular and could consist of major right-stepping ENE sinistral oblique-slip segments, cut locally by the active N-S dextral faults. Judging from the extent of the earthquakes, the minimum width of the ENE transform zone is 10 to $15 \mathrm{~km}$. But if the southernmost isolated earthquakes around Hrútsvatn belong to the SISZ, then the width of the ENE transform zone is up to $30 \mathrm{~km}$ (Figure 15(c)). The Pjórsá and the Ytri-Rangá are the main rivers within this ENE shear zone, both of which have a 
dominant ENE trace. The proposed widths, the boundaries controlled by parallel faults and the internal oblique shear fractures of the SISZ are similar to other transform zones described from slow spreading centres. It is, however, emphasised that the estimated widths in this study represent only the presently active part of the SISZ.

\subsection{Structural Fabric and Rotation of the HMP}

The location of the HMP between the WRZ and the ERZ calls for an assessment of the deformation in the presence of two rift segments and their linkage area. In case of propagating/receding rifts in fast spreading centres [11] [12] [68], the main structural features are the $\mathrm{V}$-shaped seafloor fabric, the pseudofaults, a transferred lithosphere, and an orthogonal transform zone (Figure 16(a)). However, the V-shaped geometry is also reported from oceanic slow spreading such as the RR [71]. Although these features appear also in presence of two overlapping rifts that propagate in opposite directions, generally, the deformation in the linkage area is either through bookshelf tectonics [78], or anticlockwise rotations about vertical axes both inside the rigid microplate and at its edge near the overlapping rifts [67] (Figure 16(b)). Such a rotation differs from the bookshelf tectonics within transform zones that occur along the main internal faults of the shear zone.

The above structural features should also be present in the HMP. Although these features develop over millions of years, we assess both the older (Figure 16(c)) and the present-day deformation of the study area (Figure 16(d)). The regional tectonic lineament is a key as it cuts the 3.4 Ma to present series covering the axis and both sides of the Hreppar antiform as well as the SISZ [96]. Some of the lineaments highlighted on the fracture map in the HMP, the WRZ and the SISZ (Figure 16(c)) are not an interpretation of the longest individual fractures, but a means to follow the segments of individual strikes from one structural domain to another. The highlights indicate that the same fracture sets are present in the WRZ and in the entire HMP, without evidence of a clockwise or anticlockwise rotation, a V-shape fabric and pseudofaults. Given the age of the crust and the constant spreading rate from upper Tertiary to present [100] [155], this structural fabric reflects the stability of the microplate since 3.4 Ma.

Figure 16(d) shows results of a 10-year continuous GPS monitoring, holding the American Plate fixed. The horizontal velocities are due to plate spreading, excluding volcanic inflation and deflation, and the effects of the 2000-2008 earthquakes [120]. Although the measurements cover a very short time-span and focus mostly on the SISZ and the ERZ, the velocities do not show any sensible rotation, neither within nor by the edge of the HMP and the SISZ.

\subsection{Migration and Rotation of Unstable Rifts and the Leaky SISZ}

Three structural features raise additional questions: The ENE trend of the SISZ at an oblique angle to the rift segments, the low frequency of E-W fractures, and 
the widespread presence of the Riedel shears in the HMP away from the active transform zone. To recall, a propagating rift lengthens along strike (and away from hotspot), a receding rift shortens [11] [69] [70] [73], and transform zones become unstable as a response to changes in the rate and direction of plate motion, especially near hotspots [12] [24] [35] [36]. In slow spreading centres, transform zones may develop oblique to rifts [156], and later rotate to a stable orthogonal configuration [65]. However, particularly in case of leaky or weak transform zones, these ductile shear zones may be orthogonal at depth but oblique to the rifts near the surface [66]. Regardless of the process, their obliquity and rotation lead to complex fracturing [37].

Similarly, an assessment of the angular relation of the SISZ and the two rift segments, and the instability of these boundaries in time is necessary. The following interpretations are speculative, assuming that the spreading rate remains constant in the future as in the past $3 \mathrm{Ma}$, with 35\% across the WRZ and 65\% across the ERZ, and that both rift segments continue to propagate and recede towards the southwest. However, an important parameter would be the strike of the rift segments, which is a less discussed criterion as a possible contributor to plate boundary instabilities.

Based on the distribution of the tholeiitic lavas in the fissure swarms, the presently southwestward propagating ERZ and receding WRZ trend $N 43^{\circ} \mathrm{E}$ and $\mathrm{N} 38^{\circ} \mathrm{E}$, respectively (Figure 17(a)). Our results suggest that the active part of the SISZ connecting these rift segments strikes $\sim \mathrm{N} 75^{\circ} \mathrm{E}$, and the transform zone has a maximum width of $30 \mathrm{~km}$. The high number of dykes striking similar to the shear fractures, particularly in the Hreppar formation of Skarðsfjall in the SISZ (Figure 5 and Figure 6 and Figure 14) indicates that the transform zone is likely leaky and unstable. Even if at an unstable stage the SISZ may be E-W at depth, its present near-surface expression is a strong ENE oblique-slip sinistral shear zone at an angle to the rifts. The boundaries of the transform zone are controlled by the ENE parallel faults with its internal fabric consisting of oblique Riedel shears (Figure 17(b)).

Figure 17 (c) suggests the future evolution of the plate boundaries in the southern half of Iceland, which would occur over hundreds of thousands or millions years, thus undetectable by present-day measurements. That evolution would be dominated by those sections of the two rift segments that strike $\mathrm{N} 55^{\circ} \mathrm{E}$. In fact, the $\mathrm{N} 55^{\circ} \mathrm{E}$ sections are already in place between Hengill and the Reykjanes Ridge (RR) in the WRZ, as well as from the area of the transitional crust in the ERZ to the Westmann Islands. As a consequence of the activity of the $\mathrm{N} 55^{\circ} \mathrm{E}$ sections of the rifts in the future, the direction of propagation and recession would turn slightly westward. To connect the active sections of the rifts, the transform zone would migrate, as it has done in the past [138], but also rotate clockwise. The $15^{\circ}-17^{\circ}$ clockwise rotation of the active rift segments would be the main drive for the $15^{\circ}$ clockwise rotation of the SISZ from $\mathrm{N} 75^{\circ} \mathrm{E}$ to $\mathrm{N} 90^{\circ} \mathrm{E}$ (Figure 17(c)). Such a rotation applies to the entire transform zone and differs from its internal bookshelf tectonics. After this rotation, the transform zone sta- 
bilises more, with parallel E-W boundary faults but unchanged internal Riedel shears, all compensating its sinistral motion (Figure 17(d)). As only one rift segment can propagate away from a hotspot, ultimately, the ERZ would connect to the RR via this E-W transform zone, and the WRZ would cease entirely.

\section{Conclusions}

A large number of fractures were mapped from aerial images in the SISZ, the HMP and the WRZ, along with the stratigraphy and dips of the series as well as various fracture types in the outcrops of the HMP and the SISZ. The mapped fractures from aerial images are 20,127 undifferentiated segments in the three structural domains. The outcrop data from the SISZ and the HMP are 262 basement faults, 340 dykes and cone-sheets, 110 striated planes, 1528 mineral veins, 6314 tectonic joints, 317 surface ruptures of earthquakes, and 181 present-day leakages from fractures. The structures cut series of 3.4 Ma to present, are of various relative ages, and represent the tectonics of the eroded upper oceanic crust in this slow spreading site. The main findings are:

- The regional dips show a complex antiform in the HMP, whose axis is some $5 \mathrm{~km}$ farther to the west than previously thought. Almost half of the fractures on the regional lineament map are in the WRZ, reflecting the dominance of the NNE rift-parallel extensional fractures. But this set represents only $23 \%$ of the total fracture population in the outcrops of the SISZ and the HMP where fractures of all types group into five sets with strike- and oblique-slip motions. Both within the active transform zone and in the microplate, these sets are dominantly N-S dextral and ENE sinistral, and secondarily WNW, NW and E-W sinistral, forming a Riedel shear pattern typical of a major shear zone. Striated planes generally support the fault motions. However, the few incoherent fault slip-data can be explained as a result of block adjustments near the SLCV, or as friction between fracture planes related to dyke injection.

- Fractures are reactivated over time, as evidenced by: 1) The extent of the young surface ruptures from the SISZ into the HMP where they align with older faults and dykes; 2) Present-day leakages of water from the Riedel shears; 3) Cumulative dip-slips, which are higher in the older HMP (35 m or more) and lower in the SISZ (0.5 - $1 \mathrm{~m})$. Furthermore, dykes of the SISZ and the HMP align dominantly along the Riedel shears, indicating that magma injections into shear fractures are not a rare occurrence, and that the transform zone is leaky.

- The ENE fractures are tightly parallel on both sides of the Pjórsá River and most of them dip to the southeast. They control the boundary of a narrow ENE valley that is typical of transform zones in slow spreading centres. This valley is sharp in the northeast of SISZ where it hosts the last earthquakes of the transform zone. But it does not appear to the west where earthquakes are denser, likely because the ENE transform zone is deeper there and a valley is buried under younger formations. The structural pattern, the extent of the 
earthquakes, and the dominant ENE rivers indicate a 10 to $30 \mathrm{~km}$ width for the SISZ, with an overall ENE strike highly oblique to the rifts. Its ENE sinistral oblique-slip boundaries are irregular and cut by the active N-S dextral faults.

- Although the HMP is between this ENE transform zone and two rift segments, the structural fabric of the microplate does not show evidence of rotation since 3.4 Ma. However, the future propagation of the ERZ and recession of the WRZ would be along their $\mathrm{N} 55^{\circ} \mathrm{E}$ southern sections, causing a migration of the SISZ and its clockwise rotation from ENE to E-W. At that stage, E-W boundary faults would control the SISZ, with unchanged internal Riedel shears, all compensating its sinistral motion. As only one rift can propagate away from a hotspot, the ERZ will ultimately connect to the RR via this E-W transform zone, and the WRZ would cease entirely.

Results of this research contribute to a better understanding of the geology of Iceland but also to the complexities of unstable rifts, transform zones, and microplates in slow-spreading centres in general. Such complexities control the geological processes of these varied structural domains at diverging plate boundaries where many geothermal fields and petroleum systems develop, particularly in case of fractured reservoirs. Therefore, case studies that provide observations from $\mathrm{cm}$ to tens of $\mathrm{km}$, a multidisciplinary approach, and interpretations in time and space such as in the present paper, are critical knowledge for exploration and the choice of the targets, as well as for decisions concerning the management of these resources.

\section{Acknowledgements}

The initial data used in this paper were collected during a 10-year cooperative project sponsored by Landsvirkjun (National Power Company), Orkuveita Reykjavíkur (Reykjavík Energy) and Orkustofnun (National Energy Authority), while Maryam Khodayar was a staff member of Iceland GeoSurvey (ÍSOR). We wish to thank the sponsors for their permissions to publish the results, particularly Guðlaugur Pórarinsson (Landsvirkjun), Jónas Ketilsson (Orkustofnun), and Einar Gunnlaugsson (Orkuveita Reykjavíkur). The preparation of this paper is sponsored by the Department of Hydro Power as well as the Energy Research Fund of Landsvirkjun. A part of the data collection and early interpretations were carried out in collaboration with Hjalti Franzson (Iceland GeoSurvey-ÍSOR) and Páll Einarsson (University of Iceland), and published in internal reports of ÍSOR and Landsvirkjun. The authors also thank Halldór Ármannsson (ÍSOR) as well as anonymous reviewers of the Open Journal of Geology (OJG) for fruitful comments. Joanna Cheng (Managing Editor of the journal) provided invaluable support and assistance, and the publishing department of OJG is thanked for their efforts to publish high quality figures.

\section{Conflicts of Interest}

The authors declare no conflicts of interest regarding the publication of this paper. 


\section{References}

[1] White, R.S. and Mckenzie, D. (1989) Magmatism at Rift Zones: The Generation of Volcanic Continental Margins and Flood Basalts. Journal of Geophysical Research, 94, 7685-7729. https://doi.org/10.1029/JB094iB06p07685

[2] Saunders, A.D., Fitton, J.G., Kerr, A.C., Norry, M.J. and Kent, R.W. (1997) The North Atlantic Igneous Province. In: Mahoney, J.J. and Coffin, M.L., Eds., Large Igneous Provinces, American Geophysical Union Geophysical Monograph No. 100, Washington DC, 45-93. https://doi.org/10.1029/GM100p0045

[3] DeMets, R., Gordon, G. and Argus, D.F. (2010) Geologically Current Plate Motions. Geophysical Journal International, 181, 1-80. https://doi.org/10.1111/j.1365-246X.2009.04491.X

[4] Wilson, J.T. (1965) A New Class of Faults and Their Bearing on Continental Drift. Nature, 207, 343-347. https://doi.org/10.1038/207343a0

[5] Vine, F.J. and Matthews, D.H. (1963) Magnetic Anomalies over Oceanic Ridges. Nature, 199, 947-949. https://doi.org/10.1038/199947a0

[6] Sykes, L.R. (1967) Mechanism of Earthquakes and Nature of Faulting on the Mid-Oceanic Ridges. Journal of Geophysical Research, 72, 2131-2153.

https://doi.org/10.1029/JZ072i008p02131

[7] Ostenso, N.A. (1968) Geophysical Studies in the Greenland Sea. Geological Society of America Bulletin, 79, 107-132. https://doi.org/10.1130/0016-7606(1968)79[107:GSITGS]2.0.CO;2

[8] Fossen, H. (2010) Structural Geology. Cambridge University Press, Cambridge, 463 p. https://doi.org/10.1017/CBO9780511777806

[9] Moores, E., Yikilmaz, M.B. and Kellogg, L.H. (2013) Tectonics: 50 Years after the Revolution. In: Bickford, M.E., Ed., The Web of Geological Sciences. Advances, Impacts, and Interactions, Geological Society of America Special Paper 500, Boulder, 321-369. https://doi.org/10.1130/2013.2500(10)

[10] Lonsdale, P. (1989) Segmentation of the Pacific-Nazca Spreading Center, $1^{\circ} \mathrm{N}-20^{\circ}$. Journal of Geophysical Research, 94, 12,197-12,225. https://doi.org/10.1029/JB094iB09p12197

[11] Hey, R.N. (1977) A New Class of Pseudofaults and Their Bearing on Plate Tectonics: A Propagating Rift Model. Earth and Planetary Science Letters, 37, 321-325. https://doi.org/10.1016/0012-821X(77)90177-7

[12] Atwater, T. (1981) Propagating Rifts in Seafloor Spreading Patterns. Nature, 290, 185-186. https://doi.org/10.1038/290185a0

[13] Einarsson, P. and Brandsdóttir, B. (1980) Seismological Evidence for Lateral Magma Intrusion during the 1978 Deflation of the Krafla Volcano in NE Iceland. Journal of Geophysics, 47, 160-165. https://doi.org/10.2172/890964

[14] Ebinger, C.J., Ayele, A., Keir, D., Rowland, J.V., Yirgu, G., Wright, T., Belachew, M. and Hamling, I. (2010) Length and Timescales of Rift Faulting and Magma Intrusion: The Afar Rifting Cycle from 2005 to Present. Annual Review Earth Planetary Sciences, 38, 439-466. https://doi.org/10.1146/annurev-earth-040809-152333

[15] Keir, D., Hamling, I.J., Ayele, A., Calais, E., Ebinger, C., Wright, T.J., Jacques, E., Mohamed, K., Hammond, J.O.S., Belachew, M., Baker, E., Rowland, J.V., Lewi, E. and Bennati, L. (2009) Evidence for Focused Magmatic Accretion at Segment Centers from Lateral Dike Injections Captured beneath the Red Sea Rift in Afar. Geology, 1, 59-62. https://doi.org/10.1130/G25147A.1

[16] Menard, H.W. and Atwater, T. (1968) Changes in Direction of Sea Floor Spreading. 
Nature, 219, 463-467. https://doi.org/10.1038/219463a0

[17] McKenzie, D.P. and Parker, R.L. (1967) The North Pacific: An Example of Tectonics on a Sphere. Nature, 216, 1276-1280. https://doi.org/10.1038/2161276a0

[18] Freund, R. (1974) Kinematics of Transform and Transcurrent Faults. Tectonophysics, 21, 93-134. https://doi.org/10.1016/0040-1951(74)90064-X

[19] Bellahsen, N., Leroy, S., Autin, J., Razin, P., d'Acremont, E., Sloan, H., Pik, R., Ahmed, A. and Khanbari, K. (2013) Pre-Existing Oblique Transfer Zones and Transfer/Transform Relationships in Continental Margins: New Insights from the Southeastern Gulf of Aden, Socotra Island, Yemen. Tectonophysics, 607, 32-50. https://doi.org/10.1016/j.tecto.2013.07.036

[20] Bird, D. (2001) Shear Margins: Continent-Ocean Transform and Fracture Zone Boundaries. The Leading Edge, 20, 150-159. https://doi.org/10.1190/1.1438894

[21] Taylor, B., Goodliffe, A. and Martinez, F. (2009) Initiation of Transform Faults at Rifted Continental Margins. Comptes Rendus Geoscience, 341, 428-438. https://doi.org/10.1016/j.crte.2008.08.010

[22] Gerya, T.V. (2012) Origin and Model of Oceanic Transform Faults. Tectonophysics, 522-523, 34-56. https://doi.org/10.1016/j.tecto.2011.07.006

[23] Basile, Ch. (2015) Transform Continental Margins-Part 1: Concepts and Models. Tectonophysics, 661, 1-10. https://doi.org/10.1016/j.tecto.2015.08.034

[24] D’Acremont, E., Leroy, S., Maia, M., Gente, P. and Autin, J. (2010) Volcanism, Jump and Propagation on the Sheba Ridge, Eastern Gulf of Aden: Segmentation Evolution and Implications for Oceanic Accretion Processes. Geophysical Journal International, 180, 535-551. https://doi.org/10.1111/j.1365-246X.2009.04448.x

[25] Garfunkel, Z. (1981) Internal Structure of the Dead Sea Leaky Transform (Rift) in Relation to Plate Kinematics. Tectonophysics, 80, 81-108.

https://doi.org/10.1016/0040-1951(81)90143-8

[26] Lodolo, E., Coren, F. and Ben-Avraham, Z. (2013) How Do Long-Offset Oceanic Transforms Adapt to Plate Motion Changes? The Example of the Western Pacific-Antarctic Plate Boundary. Journal of Geophysical Research, Solid Earth, 118, 1195-1202. https://doi.org/10.1002/jgrb.50109

[27] Moy, D.J. and Imber, J. (2009) A Critical Analysis of the Structure and Tectonic Significance of Rift-Oblique Lineaments ("Transfer Zones") in the Mesozoic-Cenozoic Succession of the Faroe-Shetland Basin, NE Atlantic Margin. Journal of the Geological Society, London, 166, 831-844. https://doi.org/10.1144/0016-76492009-010

[28] Abercrombie, R.E. and Ekström, G. (2001) Earthquake Slip on Oceanic Transform Faults. Nature, 410, 74-77. https://doi.org/10.1038/35065064

[29] Phipps Morgan, J. and Forsyth, D.W. (1988) Three-Dimensional Flow and Temperature Perturbations Due to a Transform Offset: Effects on Oceanic Crust and Upper Mantle Structure. Journal of Geophysical Research, 93, 2955-2966. https://doi.org/10.1029/JB093iB04p02955

[30] Shen, Y. and Forsyth, D.W. (1992) The Effects of Temperature- and Pressure-Dependent Viscosity on Three-Dimensional Passive Flow of the Mantle beneath a Ridge Transform System. Journal of Geophysical Research, 97, 19,717-19,728. https://doi.org/10.1029/92JB01467

[31] Behn, M.D., Boettcher, M.S. and Hirth, G. (2007) On the Thermal Structure of Oceanic Transform Faults. Geology, 35, 307-310.

https://doi.org/10.1130/G23112A.1 
[32] Roland, E., Behn, M.D. and Hirth, G. (2010) Thermal-Mechanical Behavior of Oceanic Transform Faults: Implications for the Spatial Distribution of Seismicity. Geochemistry, Geophysics, Geosystems, AGU, 11, Q07001. https://doi.org/10.1029/2010GC003034

[33] Hensen, Ch., Duarte, J.C., Vannucchi, P., Mazzini, A., Lever, M.A., Terrinha, P., Géli, L., Henry, P., Villinger, H., Morgan, J., Schmidt, M., Gutscher, M.A., Bartolome, R., Tomonaga, Y., Polonia, A., Gràcia, E., Tinivella, U., Lupi, M., Çagatay, N.M., Elvert, M., Sakellariou, D., Matias, L., Kipfer, R., Karageorgis, A.P., Ruffine, L., Liebetrau, V., Pierre, C., Schmidt, Ch., Batista, L., Gasperini, L., Burwicz, E., Neres, M. and Nuzzo, M. (2019) Marine Transform Faults and Fracture Zones: A Joint Perspective Integrating Seismicity, Fluid Flow and Life. Frontiers in Earth Science, 7, 39. https://doi.org/10.3389/feart.2019.00039

[34] Ron, H., Freund, R., Garfunkel, Z. and Nur, A. (1984) Block Rotation by Strike-Slip Faulting: Structural and Paleomagnetic Evidence. Journal of Geophysical Research, 89, 6256-6270. https://doi.org/10.1029/JB089iB07p06256

[35] Kleinrock, M.C. and Hey, R.N. (1989) Migrating Transform Zone and Lithospheric Transfer at the Galapagos $95.5^{\circ} \mathrm{W}$ Propagator. Journal of Geophysical Research, 94, 13859-13878. https://doi.org/10.1029/JB094iB10p13859

[36] Phipps Morgan, J. and Kleinrock, M.C. (1991) Transform Migration: Implication of Bookshelf Faulting at Oceanic and Icelandic Propagating Ridges. Tectonics, 10, 920-935. https://doi.org/10.1029/90TC02481

[37] Dauteuil, O., Bourgeois, O. and Mauduit, T. (2002) Lithosphere Strength Controls Oceanic Transform Zone Structure: Insights from Analogue Models. Geophysical Journal International, 150, 706-714.

https://doi.org/10.1046/j.1365-246X.2002.01736.x

[38] Fox, P.J. and Gallo, D.G. (1984) A Tectonic Model for Ridge-Transform-Ridge Plate Boundaries: Implications for the Structure of Oceanic Lithosphere. Tectonophysics, 104, 205-242. https://doi.org/10.1016/0040-1951(84)90124-0

[39] Nemčok, M., Rybár, S., Sinh, S.T., Hermeston, S.A. and Ledvényiova, L. (2016) Transform Margins: Development, Controls and Petroleum Systems: An Introduction. In: Nemčok, M., Rybár, S., Sinh, S.T., Hermeston, S.A. and Ledvényiova, L., Eds., Transform Margins. Development, Controls and Petroleum Systems, Geological Society, London, Special Publications, 431, 1-38.

https://doi.org/10.1144/SP431.15

[40] Riedel, W. (1929) Zur Mechanik geologischer Brucherscheinungen. Zentralblatt für Mineralogie, Geologie und Paleontologie, 1929B, 354-368.

[41] Tchalenko, J.S. (1970) Similarities between Shear Zones of Different Magnitudes. Geological Society America Bulletin, 81, 1625-1640. https://doi.org/10.1130/0016-7606(1970)81[1625:SBSZOD]2.0.CO;2

[42] Dooley, T., McClay, K. and Bonora, M. (1999) 4D Evolution of Segmented Strike-Slip Fault Systems: Applications to NW Europe. In: Fleet, A. and Boldy, S., Eds., Petroleum Geology of Northwest Europe: Proceedings of the 5t $h$ Conference, Petroleum Geology'86, Geological Society, London, 215-225. https://doi.org/10.1144/0050215

[43] Aydin, A. and Nur, A. (1985) The Types and Role of Stepovers in Strike-Slip Tectonics. In: Biddle, K.T. and Christie-Blick, N., Eds., Strike-Slip Deformation, Basin Formation, and Sedimentation, Society of Economic Paleontologists and Mineralogists, Ponca City, Special Publications No. 37, 35-44.

https://doi.org/10.2110/pec.85.37.0035 
[44] Christie-Blick, N. and Biddle, K.T. (1985) Deformation and Basin Formation along Strike-Slip Faults. In: Biddle, K.T. and Christie-Blick, N., Eds., Strike-Slip Deformation, Basin Formation, and Sedimentation, Society of Economic Paleontologists and Mineralogists, Ponca City, Special Publications No. 37, 1-34. https://doi.org/10.2110/pec.85.37.0001

[45] McClay, K. and Bonora, M. (2001) Analog Models of Restraining Stepovers in Strike-Slip Fault Systems. American Association of Petroleum Geologists Bulletin, 85, 233-260.

[46] Crowell, J.C. (1974) Origin of Late Cenozoic Basins of Southern California. In: Dickinson, W.R., Ed., Tectonics and Sedimentation, Society of Economic Paleontologists and Mineralogists, Ponca City, Special Publications No. 22, 190-204. https://doi.org/10.2110/pec.74.22.0190

[47] Garfunkel, Z. (1986) Review of Oceanic Transform Activity and Development. Journal of the Geological Society, London, 143, 775-784.

https://doi.org/10.1144/gsigs.143.5.0775

[48] Legg, M.R., Goldfinger, C., Kamerling, M.J., Chaytor, J.D. and Einstein, D.E. (2007) Morphology, Structure and Evolution of California Continental Borderland Restraining Bends. In: Cunningham, W.D. and Mann, P., Eds., Tectonics of Strike-Slip Restraining and Releasing Bends, Geological Society, London, Special Publications No. 290, 143-168. https://doi.org/10.1144/SP290.3

[49] Ben-Avraham, Z. and Zoback, M.D. (1992) Transform-Normal Extension and Asymmetric Basins: An Alternative to Pull-Apart Models. Geology, 20, 423-426. https://doi.org/10.1130/0091-7613(1992)020<0423:TNEAAB >2.3.CO;2

[50] Waldron, J. (2004) Anatomy and Evolution of a Pullapart Basin, Stellarton, Nova Scotia. Geological Society of America Bulletin, 116, 109-127.

https://doi.org/10.1130/B25312.1

[51] Smit, J., Brun, J.P., Cloetingh, S. and Ben-Avraham, Z. (2008) Pull-Apart Basin Formation and Development in Narrow Transform Zones with Application to the Dead Sea Basin. Tectonics, 27, TC6018. https://doi.org/10.1029/2007TC002119

[52] Rosenthal, M., Ben-Avraham, Z. and Schattner, B. (2019) Almost a Sharp Cut: A Case Study of the Cross Point between a Continental Transform and a Rift, Based on 3D Gravity Modelling. Tectonophysics, 761, 46-64. https://doi.org/10.1016/j.tecto.2019.04.012

[53] Mamula, N. and Voight, B. (1985) Tectonic Analysis of Lineaments near a Spreading Axis, Northeastern Iceland. Tectonophysics, 116, 63-93. https://doi.org/10.1016/0040-1951(85)90222-7

[54] Garcia, S. and Dhont, D. (2005) Structural Analysis of the Húsavík-Flatey Transform Fault and Its Relationships with the Rift System in Northern Iceland. Geodinamica Acta, 18, 31-41. https://doi.org/10.3166/ga.18.31-41

[55] Khodayar, M. and Björnsson, S. (2018) Structures and Styles of Deformation in Rift, Ridge, Transform Zone, Oblique Rift and a Microplate Offshore/Onshore North Iceland. International Journal of Geosciences, 9, 461-511. https://doi.org/10.4236/ijg.2018.98029

[56] Morley, C.K., Nelson, R.A., Patton, T.L. and Munn, S.G. (1990) Transfer Zones in the East African Rift System and Their Relevance to Hydrocarbon Exploration in Rifts. American Association of Petroleum Geologists Bulletin, 74, 1234-1253.

[57] Gawthorpe, R.L. and Hurst, M. (1993) Transfer Zones in Extensional Basins: Their Structural Style and Influence on Drainage Development and Stratigraphy. Journal of the Geological Society, London, 150, 1137-1152. 
https://doi.org/10.1144/gsjgs.150.6.1137

[58] Chorowicz, J. (2005) The East African Rift System. Journal of African Earth Sciences, 43, 379-410. https://doi.org/10.1016/j.jafrearsci.2005.07.019

[59] Corti, G. (2009) Continental Rift Evolution: From Rift Initiation to Incipient Break-Up in the Main Ethiopian Rift, East Africa. Earth Science Reviews, 96, 1-53. https://doi.org/10.1016/j.earscirev.2009.06.005

[60] Gomes, C.P., Fossen, H., Paes de Almeidaa, R. and Salmonia, B. (2018) Subseismic Deformation in the Vaza-Barris Transfer Zone in the Cretaceous Recôncavo-Tucano-Jatobá Rift System, NE Brazil. Journal of Structural Geology, 117, 81-95. https://doi.org/10.1016/j.jsg.2018.09.007

[61] Segall, P. and Pollard, D.D. (1983) Nucleation and Growth of Strike Slip Faults in Granite. Journal of Geophysical Research, 88, 555-568. https://doi.org/10.1029/JB088iB01p00555

[62] Harding, T.P., Vierbuchen, R.C. and Christie-Blick, N. (1985) Structural Styles, Plate-Tectonic Settings, and Hydrocarbon Traps of Divergent (Transtensional) Wrench Faults. In: Biddle, K.T. and Christie-Blick, N., Eds., Strike-Slip Deformation, Basin Formation, and Sedimentation, Society of Economic Paleontologists and Mineralogists, Ponca City, Special Publication No. 37, 51-77. https://doi.org/10.2110/pec.85.37.0051

[63] Kim, Y.S., Peacock, D.C.P. and Sanderson, D.J. (2004) Fault Damage Zones. Journal of Structural Geology, 26, 503-517. https://doi.org/10.1016/j.jsg.2003.08.002

[64] Muirhead, J.D. and Kattenhorn, S.A. (2018) Activation of Preexisting Transverse Structures in an Evolving Magmatic Rift in East Africa. Journal of Structural Geology, 106, 1-18. https://doi.org/10.1016/j.jsg.2017.11.004

[65] Oldenburg, D.W. and Brune, J.N. (1975) An Explanation for the Orthogonality of Ocean Ridges and Transform Faults. Journal of Geophysical Research, 80, 2575-2585. https://doi.org/10.1029/JB080i017p02575

[66] Marques, F.O. (2012) Transform Faults Orthogonal to Rifts: Insights from Fully Gravitational Physical Experiments. Tectonophysics, 526-529, 42-47. https://doi.org/10.1016/j.tecto.2011.08.018

[67] Schouten, H., Klitgord, K.D. and Gallo, D.G. (1993) Edge-Driven Microplate Kinematics. Journal of Geophysical Research, 98, 6689-6701. https://doi.org/10.1029/92JB02749

[68] Hey, R.N. (2004) Propagating Rifts and Microplates at Mid-Ocean Ridges. In: Selley, R.C., Ed., Encyclopaedia of Geology, Academic Press, London, 396-405. https://doi.org/10.1016/B978-0-12-409548-9.03027-X

[69] Ebinger, C.J., Crow, M.J., Rosendahl, B.R., Livingstone, D.L. and Le Fournier, J. (1984) Structural Evolution of Lake Malawi, Africa. Nature, 308, 627-629. https://doi.org/10.1038/308627a0

[70] Nelson, R.A., Patton, T.L. and Morley, C.K. (1992) Rift-Segment Interaction and Its Relation to Hydrocarbon Exploration in Continental Rift Systems. The American Association of Petroleum Geologists Bulletin, 76, 1153-1169.

[71] Hey, R., Martinez, F., Höskuldsson, Á. and Benediktsdóttir, Á. (2010) Propagating Rift Model for the V-Shaped Ridges South of Iceland. AGU, Geochemistry, Geophysics, Geosystems, 11, Q03011. https://doi.org/10.1029/2009GC002865

[72] Morgan, W.J. (1971) Convection Plumes in the Lower Mantle. Nature, 230, 42-43. https://doi.org/10.1038/230042a0

[73] Phipps Morgan, J. and Parmentier, E.M. (1985) Causes and Rate-Limiting Mechan- 
isms of Ridge Propagation: A Fracture Mechanics Model. Journal of Geophysical Research, 90, 8603-8612. https://doi.org/10.1029/JB090iB10p08603

[74] Sandwell, D.T., Müller, R.D., Smith, W.H.F., Garcia, E. and Francis, R. (2014) New Global Marine Gravity Model from Cryo-Sat-2 and jason-1 Reveals Buried Tectonic Structure. Science, 346, 65-67. https://doi.org/10.1126/science.1258213

[75] Pollard, D.D. and Aydin, A. (1984) Propagation and Linkage of Oceanic Ridge Segments. Journal of Geophysical Research, 89, 10,017-10,028. https://doi.org/10.1029/JB089iB12p10017

[76] Freund, R. (1970) Rotation of Strike-Slip Faults in Sistan, Southeastern Iran. Journal of Geology, 78, 188-200. https://doi.org/10.1086/627500

[77] Courtillot, V., Achache, J., Landre, F., Bonhommet, N., Montigny, R. and Féraud, G. (1984) Episodic Spreading and Rift Propagation: New Paleomagnetic and Geochronologic Data from the Afar Nascent Passive Margin. Journal of Geophysical Research, 89, 3315-3333. https://doi.org/10.1029/JB089iB05p03315

[78] Tapponnier, P., Armijo, R., Manighetti, I. and Courtillot, V. (1990) Bookshelf Faulting and Horizontal Block Rotations between Overlapping Rifts in Southern Afar. Geophysical Research Letters, 17, 1-4. https://doi.org/10.1029/GL017i001p00001

[79] Manighetti, I., Tapponnier, P., Courtillot, V., Gallet, Y., Jacques, E. and Gillot, P. Y. (2001) Strain Transfer between Disconnected, Propagating Rifts in Afar. Journal of Geophysical Research, 106, 13613-13665. https://doi.org/10.1029/2000JB900454

[80] Hey, R.N., Martinez, F., Diniega, S., Naar, D.F., Francheteau, J., Armijo, R., Constantin, M., Cogné, J.P., Girardeau, J., Hekinian, R. and Searle, R. (2002) Preliminary Attempt to Characterize the Rotation of Seafloor in the Pito Deep Area of the Easter Microplate Using a Submersible Magnetometer. Marine Geophysical Researches, 23, 1-12. https://doi.org/10.1023/A:1021257915420

[81] Searle, R.C. and Hey, R.N. (1983) GLORIA Observations of the Propagating Rift at $95.5^{\circ} \mathrm{W}$ on the Cocos-Nazca Spreading Center. Journal of Geophysical Research, 88, 6433-6447. https://doi.org/10.1029/JB088iB08p06433

[82] Engeln, J.F., Stein, S., Werner, J. and Gordon, R.G. (1988) Microplate and Shear Zone Models for Oceanic Spreading Center Reorganizations. Journal of Geophysical Research, 93, 2839-2856. https://doi.org/10.1029/JB093iB04p02839

[83] Einarsson, P. (2008) Plate Boundaries, Rifts and Transforms in Iceland. Jökull, 58, 35-58.

[84] Einarsson, P., Klein, F.W. and Björnsson, S. (1977) The Borgarfjörður Earthquakes in West Iceland 1974. Seismological Society of America Bulletin, 67, 187-208.

[85] Sigurðsson, H. (1970) Structural Origin and Plate Tectonics of the Snæfellsnes Volcanic Zone, Western Iceland. Earth and Planetary Science Letters, 10, 129-135. https://doi.org/10.1016/0012-821X(70)90074-9

[86] Jakobsson, S.P. (1972) Chemistry and Distribution Pattern of Recent Basaltic Rocks in Iceland. Lithos, 5, 365-386. https://doi.org/10.1016/0024-4937(72)90090-4

[87] Tryggvason, E. (1959) Earthquakes in Iceland during the Years 1956, 1957, 1958. Náttúrufræðingurinn, 29, 84-91. (In Icelandic)

[88] Ward, P.L. (1971) New Interpretation of the Geology of Iceland. Geological Society of America Bulletin, 82, 2991-3012. https://doi.org/10.1130/0016-7606(1971)82[2991:NIOTGO]2.0.CO;2

[89] Brandsdóttir, B., Riedel, C., Richter, B., Helgadóttir, G., Kjartansson, E., Detrick, R., Dahm, T., Mayer, L., Calder, B. and Driscoll, N. (2005) Multibeam Bathymetric 
Maps of the Kolbeinsey Ridge and Tjörnes Fracture Zone, N-Iceland. Abstract European Geophysical Union General Assembly, Nice.

[90] Hreinsdóttir, S., Einarsson, P. and Sigmundsson, F. (2001) Crustal Deformation at the Oblique Spreading Reykjanes Peninsula, SW Iceland: GPS Measurements from 1993 to 1998. Journal of Geophysical Research, 106, 13803-13816.

https://doi.org/10.1029/2001JB000428

[91] Talwani, M. and Eldholm, O. (1977) Evolution of the Norwegian-Greenland Sea. Geological Society of America Bulletin, 88, 969-999. https://doi.org/10.1130/0016-7606(1977)88<969:EOTNS>2.0.CO;2

[92] Harðarson, B.S., Fitton, J.G., Ellam, R.M. and Pringle, M.S. (1997) Rift Relocation: A Geochemical and Geochronological Investigation of a Paleo-Rift in Northwest Iceland. Earth and Planetary Science Letters, 153, 181-196. https://doi.org/10.1016/S0012-821X(97)00145-3

[93] Jóhannesson, H. (1980) Evolution of the Rift Zones in Western Iceland (in Icelandic with English Summary). Náttúrufraedingurinn, 50, 13-31.

[94] Jancin, M., Young, K.D., Voight, B., Aronson, J.L. and Saemundsson, K. (1985) Stratigraphy and K/Ar Ages across the West Flank of the Northeast Iceland Axial Rift Zone, in Relation to the $7 \mathrm{Ma}$ Volcano-Tectonic Reorganization of Iceland. Journal of Geophysical Research, 90, 9961-9985. https://doi.org/10.1029/JB090iB12p09961

[95] McDougall, I., Saemundsson, K., Jóhannesson, H., Watkins, N.D. and Kristjánsson, L. (1977) Extension of the Geomagnetic Polarity Time Scale to 6.5 m.y.: K-Ar Dating, Geological and Paleomagnetic Study of a 3,500 m Lava Succession in Western Iceland. Bulletin of Geological Society of America, 88, 1-15. https://doi.org/10.1130/0016-7606(1977)88<1:EOTGPT>2.0.CO;2

[96] Kristjánsson, L. and Jónsson, G. (1998) Aeromagnetic Results and the Presence of an Extinct Rift Zone in Western Iceland. Journal of Geodynamics, 25, 99-108. https://doi.org/10.1016/S0264-3707(97)00009-4

[97] Sæmundsson, K. (1978) Fissure Swarms and Central Volcanoes of the Neovolcanic Zones of Iceland. Geological Journal, Special Issue, 10, 415-432.

[98] Garcia, S., Arnaud, N.O., Angelier, J., Bergerat, F. and Homberg, C. (2003) Rift Jump Process in Northern Iceland since $10 \mathrm{Ma}$ from 40Ar/39Ar Geochronology. Earth and Planetary Science Letters, 214, 529-544. https://doi.org/10.1016/S0012-821X(03)00400-X

[99] Helgason, J. (1984) Frequent Shifts of the Volcanic Zone in Iceland. Geology, 12, 212-216. https://doi.org/10.1130/0091-7613(1984)12<212:FSOTVZ>2.0.CO;2

[100] Martin, E., Paquette, J.L., Bosse, V., Ruffet, G., Tiepolo, M. and Sigmarsson, O. (2011) Geodynamics of Rift-Plume Interaction in Iceland as Constrained by New 40Ar/39Ar and in Situ U-Pb Zircon Ages. Earth and Planetary Science Letters, 311, 28-38. https://doi.org/10.1016/j.epsl.2011.08.036

[101] Sigurðsson, H. (1967) Dykes, Fractures and Folds in the Basalt Plateau of Western Iceland. In: Björnsson, S., Ed., Iceland and Mid-Ocean Ridges, Societas Scientiarum Islandica, Vol. 38, Prentsmiđjan Leiftur, Reykjavik, 162-169.

[102] Schäfer, K. (1972) Transform Faults in Island. Geologische Rundschau, 61, 942-960. https://doi.org/10.1007/BF01820899

[103] Khodayar, M. and Einarsson, P. (2002) Strike-Slip Faulting, Normal Faulting and Lateral Dyke Injections along a Single Fault: Field Example of the Gljúfurá Fault near a Tertiary Oblique Rift/Transform Zone, Borgarfjörður, W-Iceland. Journal of Geophysical Research, 107, ETG 5-1-ETG 5-16. 
https://doi.org/10.1029/2001JB000150

[104] Voight, B. and Mamula, N. (1983) Structure and Tectonics of Northeastern Iceland. In: Estes, J.E. and Thorley, G.A., Eds., Manual of Remote Sensing, 2nd Edition, American Society of Photogrammetry, Falls Church, 1782-1786.

[105] Young, K.D., Jancin, M., Voight, B. and Orkan, N.I. (1985) Transform Deformation of Tertiary Rocks along the Tjörnes Fracture Zone, North Central Iceland. Journal of Geophysical Research, 90, 9986-10,010. https://doi.org/10.1029/JB090iB12p09986

[106] Foulger, G.R. (2006) Older Crust Underlies Iceland. Geophysical Journal International, 165, 672-676. https://doi.org/10.1111/j.1365-246X.2006.02941.X

[107] Gaina, C., Nasuti, A., Kimbell, G.S. and Blischke, A. (2017) Break-Up and Seafloor Spreading Domains in the NE Atlantic. In: Péron-Pinvidic, G., Hopper, J.R., Stoker, M.S., Gaina, C., Doornenbal, J.C., Funck, T. and Árting U.E., Eds., The NE Atlantic Region: A Reappraisal of Crustal Structure, Tectonostratigraphy and Magmatic Evolution, Geological Society, London, Special Publications No. 447, 393-417. https://doi.org/10.1144/SP447.12

[108] Bodvarsson, G. and Walker, G.P.L. (1964) Crustal Drift in Iceland. The Geophysical Journal of the Royal Astronomical Society, 8, 285-300.

https://doi.org/10.1111/j.1365-246X.1964.tb06295.x

[109] Jakobsson, S.P., Jónasson, K. and Sigurðsson, I.A. (2008) The Three Igneous Rock Series of Iceland. Jökull, 58, 117-138.

[110] Walker, G.P.L. (1960) Zeolite Zones and Dike Distribution in Relation to the Structure of the Basalts of Eastern Iceland. Journal of Geology, 68, 515-528. https://doi.org/10.1086/626685

[111] Walker, G.P.L. (1974) The Structure of Eastern Iceland. In: Kristjansson, L., Ed., Geodynamics of Iceland and the North Atlantic Area: NATO ASI, Reidel Publishing Company, Dordrecht, 177-188. https://doi.org/10.1007/978-94-010-2271-2 12

[112] Sæmundsson, K. (1970) Interglacial Lava Flows in the Lowlands of Southern Iceland and the Problem of Two-Tiered Columnar Jointing. Jökull, 20, 62-77.

[113] Jakobsdóttir, S.S. (2008) Seismicity in Iceland: 1994-2007. Jökull, 58, 75-100.

[114] Rögnvaldsson, S., Guðmundsson, A. and Slunga, R. (1998) Seismotectonic Analysis of the Tjörnes Fracture Zone, an Active Transform Fault in North Iceland. Journal of Geophysical Research, 103, 30117-30129. https://doi.org/10.1029/98JB02789

[115] Stefánsson, R., Guðmundsson, G.B. and Halldórsson, P. (2008) Tjörnes Fracture Zone. New and Old Seismic Evidences for the Link between the North Iceland Rift Zone and the Mid-Atlantic Ridge. Tectonophysics, 447, 117-126. https://doi.org/10.1016/j.tecto.2006.09.019

[116] Decriem, J., Árnadóttir, T., Hooper, A., Geirsson, H., Sigmundsson, F., Keiding, M., Ófeigsson, B.G., Hreinsdóttir, S., Einarsson, P., LaFemina, P. and Bennett, R.A. (2010) The 2008 May 29 Earthquake Doublet in SW Iceland. Geophysical Journal International, 181, 1128-1146. https://doi.org/10.1111/j.1365-246X.2010.04565.x

[117] Khodayar, M. and Björnsson, S. (2014) Fault Ruptures and Geothermal Effects of the Second Earthquake, 29 May 2008, South Iceland Seismic Zone. Geothermics, 50, 44-65. https://doi.org/10.1016/j.geothermics.2013.07.002

[118] Sigurðsson, F. (1985) Groundwater and Hydrogeology on the Outer Reykjanes Peninsula, III. Appendix on Tectonics. National Energy Authority of Iceland Report, OS-85075/VOD-06, 43 p. (In Icelandic)

[119] Arnórsson, S., Axelsson, G. and Sæmundsson, K. (2008) Geothermal Systems in Iceland. Jökull, 51, 269-302. 
[120] Sigmundsson, S., Einarsson, P., Hjartardóttir, Á. Drouin, V., Jónsdóttir, K., Árnadóttir, Th., Geirsson, H., Hreinsdóttir, S., Li, S. and Ófeigsson, B.G. (2018) Geodynamics of Iceland and the Signatures of Plate Spreading. Journal of Volcanology and Geothermal Research. https://doi.org/10.1016/j.jvolgeores.2018.08.014

[121] La Femina, P.C., Dixon, T.H., Malservisi, R., Árnadóttir, Th., Sturkell, E., Sigmundsson, F. and Einarsson, P. (2005) Geodetic GPS Measurements in South Iceland: Strain Accumulation and Partitioning in a Propagating Ridge System. Journal of Geophysical Research, 110, B11405. https://doi.org/10.1029/2005JB003675

[122] Jóhannesson, H. and Sæmundsson, K. (1998) Geological Map of Iceland: Tectonics, 1:500.000. Icelandic Institute of Natural History, Reykjavík, 1 Sheet.

[123] Walker, G.P.L. (1963) The Breiddalur Central Volcano, Eastern Iceland. Quaternary Journal of Geological Society of London, 119, 29-63.

https://doi.org/10.1144/gsigs.119.1.0029

[124] Pálmason, G. (1973) Kinematics and Heat Flow in a Volcanic Rift Zone with Application to Iceland. Geophysical Journal of the Royal Astronomical Society, 33, 451-481. https://doi.org/10.1111/j.1365-246X.1973.tb02379.x

[125] Aronson, J.L. and Sæmundsson, K. (1975) Relatively Old Basalts from Structurally High Areas in Central Iceland. Earth and Planetary Science Letters, 28, 83-97. https://doi.org/10.1016/0012-821X(75)90077-1

[126] Khodayar, M., Björnsson, S. and Franzson, H. (2011) Hvammsvirkjun, Holtavirkjun, Urriðafossvirkjun: Synthesis of 2001-2010 Geological Data from Hreppar and South Iceland Seismic Zone. Iceland GeoSurvey, Report ÍSOR-2011/032, and Landsvirkjun Report LV-2011/073, 80 p., 11 Maps.

[127] Hjartarson, Á. (2003) The Skagafjörður Unconformity, North Iceland, and Its Geological History. Geological Museum, University of Copenhagen, Copenhagen, $\mathrm{PhD}$ Thesis, $248 \mathrm{p}$.

[128] Bjarnason, I.P., Menke, W., Flóvenz, Ó.G. and Caress, D. (1993) Tomographic Image of the Mid-Atlantic Plate Boundary in Southwestern Iceland. Journal of Geophysical Research, 98, 6607-6622. https://doi.org/10.1029/92JB02412

[129] Bjarnason, I.P. (2008) An Iceland Hotspot Saga. Jökull, 58, 3-16.

[130] Flóvenz, Ó.G. and Steingrímsson, B. (2009) The Geothermal Resources of Iceland. Geothermal Research Council Transactions, 33, 383-387.

[131] Geirsson, H., LaFemina, P., Árnadóttir, Th., Sturkell, E., Sigmundsson, F., Travis, M., Schmidt, P., Lund, B., Hreinsdóttir, S. and Bennett, R. (2012) Volcano Deformation at Active Plate Boundaries: Deep Magma Accumulation at Hekla Volcano and Plate Boundary Deformation in South Iceland. Journal of Geophysical Research, 117, B11409. https://doi.org/10.1029/2012JB009400

[132] Björnsson, G., Flovenz, Ó.G., Saemundsson, K. and Einarsson, E.H. (2001) Pressure Changes in Icelandic Geothermal Reservoirs Associated with Two Large Earthquakes in June 2000. Proceedings, Twenty-Sixth Workshop on Geothermal Reservoir Engineering, Stanford, 29-31 January 2001, SGP-TR-168, 8 p.

[133] Einarsson, P. (1991) Earthquakes and Present-Day Tectonism in Iceland. Tectonophysics, 189, 261-279. https://doi.org/10.1016/0040-1951(91)90501-I

[134] Björnsson, S. (1976) Earthquakes in South Iceland: Regional Planning for Ölfus and Hveragerði. Chapter II D, Teiknistofan Höfði, Reykjavík. (In Icelandic)

[135] Rögnvaldsson, S.Th. (2000) Mapping of Active Faults with the Help of Micro Earthquakes: Overview. Report Icelandic Meteorological Office, VÍ-R00001-JA01, $15 \mathrm{p}$. 
[136] Hjaltadóttir, S. (2010) Use of Relatively Located Microearthquakes to Map Fault Patterns and Estimate the Thickness of the Brittle Crust in Southwest Iceland. Master Thesis, University of Iceland, Reykjavík, $104 \mathrm{p}$.

[137] Brandsdóttir, B., Parsons, M., White, R.S., Guðmundsson, Ó., Drew, J. and Porbjarnardóttir, B.S. (2010) The May 29th 2008 Earthquake Aftershock Sequence within the South Icelandic Seismic Zone: Fault Locations and Source Parameters of Aftershocks. Jökull, 60, 23-46.

[138] Khodayar, M. and Franzson, H. (2007) Fracture Pattern of Thjórsárdalur Central Volcano with Respect to Rift-Jump and a Migrating Transform Zone in South Iceland. Journal of Structural Geology, 29, 898-912.

https://doi.org/10.1016/j.jsg.2006.11.007

[139] Jakobsdóttir, S.S. and Guðmundsson, G.B. (2012) Earthquake Activity in Hellisheiði and Nesjavellir. Spring Conference Geological Society of Iceland, April 2012. (In Icelandic)

[140] Einarsson, P., Khodayar, M., Clifton, A., Ófeigsson, B., Porbjarnarson, S., Einarsson, B. and Hjartardóttir, Á.R. (2005) A Map of Holocene Fault Structures in the South Iceland Seismic Zone. General European Geosciences Union Assembly, Vienna, AbstractEGU05-A-08858.

[141] Einarsson, P. (2010) Mapping of Holocene Surface Ruptures in the South Iceland Seismic Zone. Jökull, 60, 117-134.

[142] Khodayar, M., Franzson, H., Björnsson, S., Víkingsson, S. and Jónsdóttir, G.S. (2004) Tectonic Lineaments of Borgarfjörður-Hvalfjörður from Aerial Photographs, West Iceland: Preliminary Results. Report Iceland GeoSurvey, ÍSOR-2004/021, 47 p., 1 Map.

[143] Khodayar, M., Björnsson, S., Guðnason, E.Á., Níelsson, S., Axelsson, G. and Hickson, C. (2018) Tectonic Control of the Reykjanes Geothermal Field in the Oblique Rift of SW Iceland: From Regional to Reservoir Scales. Open Journal of Geology, 8, 333-382. https://doi.org/10.4236/ojg.2018.83021

[144] Khodayar, M., Björnsson, S., Kristinsson, S.G., Karlsdóttir, R., Ólafsson, M. and Víkingsson, S. (2018) Tectonic Control of the Theistareykir Geothermal Field by Rift and Transform Zones in North Iceland: A Multidisciplinary Approach. Open Journal of Geology, 8, 543-584. https://doi.org/10.4236/ojg.2018.86033

[145] Friðleifsson, I.B., Haraldsson, G.I., Georgsson, L.S., Gunnlaugsson, E. and Björnsson, B.J. (1980) Geothermal Activity in Gnúpverjahreppur, Overview. Report Orkustofnun, OS80010/JHD06, $136 \mathrm{p}$.

[146] Khodayar, M. (1999) On the Pattern of Faults and Dykes in Borgarfjörður, Western Iceland. Jökull, 47, 21-44.

[147] Hjaltadóttir, S. and Vogfjörð, K. (2005) Subsurface Fault Mapping in Southwest Iceland by Relative Location of Aftershocks of the June 2000 Earthquakes. Icelandic Meteorological Institute, Veðurstofan, Report VÍ-ES-01, 18 p.

[148] Guðmundsson, Á., Kaiser, S., Ward, T., Hallsteinsson, H. and Fahrenberger, W. (2007) Urriðafoss Hydroelectric Project: Geological Investigations 2001 to 2007, Dam and Tunnelling Area. Report, Jarðfræðistofan, Published by Landsvirkjun, LV-2007/060, $47 \mathrm{p}$.

[149] Clifton, A.E. and Einarsson, P. (2005) Styles of Surface Rupture Accompanying the June 17 and 21, 2000 Earthquakes in the South Iceland Seismic Zone. Tectonophysics, 396, 141-159. https://doi.org/10.1016/j.tecto.2004.11.007

[150] Ziegler, M., Rajabi, M., Heidbacha, O., Hersir, G.P., Ágústsson, K., Árnadóttir, S. and Zang, A. (2016) The Stress Pattern of Iceland. Tectonophysics, 674, 101-113. 
https://doi.org/10.1016/j.tecto.2016.02.008

[151] Bergerat, F. and Angelier, J. (2000) The South Iceland Seismic Zone: Tectonic and Seismotectonic Analyses Revealing the Evolution from Rifting to Transform Motion. Journal of Geodynamics, 29, 211-231. https://doi.org/10.1016/S0264-3707(99)00046-0

[152] Khodayar, M. (2018) Shift of a Rift by a Transform Zone: Case from Northern Rift Zone and Tjörnes Fracture Zone of Iceland. Petroleum Geoscience, Thematic Set: Rifts III: Catching the Wave, the Geological Society of London and EAGE, 11 p. https://doi.org/10.1144/petgeo2016-132

[153] Sigmundsson, F., Hooper, A., Hreinsdottir, S., Vogfjörð, K.S., Ófeigsson, B.G., Heimisson, E.R., Dumont, S., Parks, M., Spaans, K., Gudmundsson, G.B., Drouin, V., Arnadottir, T., Jonsdottir, K., Gudmundsson, M.T., Hognadottir, T., Fridriksdottir, H.M., Hensch, M., Einarsson, P., Magnusson, E., Samsonov, S., Brandsdottir, B., White, R.S., Agustsdottir, T., Greenfield, T., Green, R.G., Hjartardottir, A.R., Pedersen, R., Bennett, R.A., Geirsson, H., La Femina, P.C., Bjornsson, H., Palsson, F., Sturkell, E., Bean, C.J., Mollhoff, M., Braiden, A.K. and Eibl, E.P.S. (2015) Segmented Lateral Dyke Growth in a Rifting Event at Bardarbunga Volcanic System, Iceland. Nature, 517, 191-195. https://doi.org/10.1038/nature14111

[154] Einarsson, P., Björnsson, S., Foulger, G., Stefánsson, R. and Skaftadóttir, T. (1981) Seismicity Pattern in the South Iceland Seismic Zone. In: Simpson, D. and Richards, P., Eds., Earthquake Prediction, Maurice Ewing Series No. 4, AGU, Washington DC, 141-151. https://doi.org/10.1029/ME004p0141

[155] DeMets, R., Gordon, G., Argus, D.F. and Stein, S. (1994) Effect of Recent Revisions to the Geomagnetic Reversal Time Scale on Estimates of Current Plate Motions. Geophysical Research Letter, 21, 2191-2194. https://doi.org/10.1029/94GL02118

[156] Atwater, T. and MacDonald, K.C. (1977) Are Spreading Centres Perpendicular to Their Transform Faults? Nature, 270, 715-719. https://doi.org/10.1038/270715a0

[157] Hey, R.N., Duennebier, F.K. and Morgan, W.J. (1980) Propagating Rifts on Mid-Ocean Ridges. Journal of Geophysical Research, 85, 3647-3658.

https://doi.org/10.1029/JB085iB07p03647 